Linköping Studies in Science and Technology. Licentiate Thesis No. 1888

\title{
Towards the Control of Microplastic Pollution in Urban Waters
}

\section{Emma Fältström}

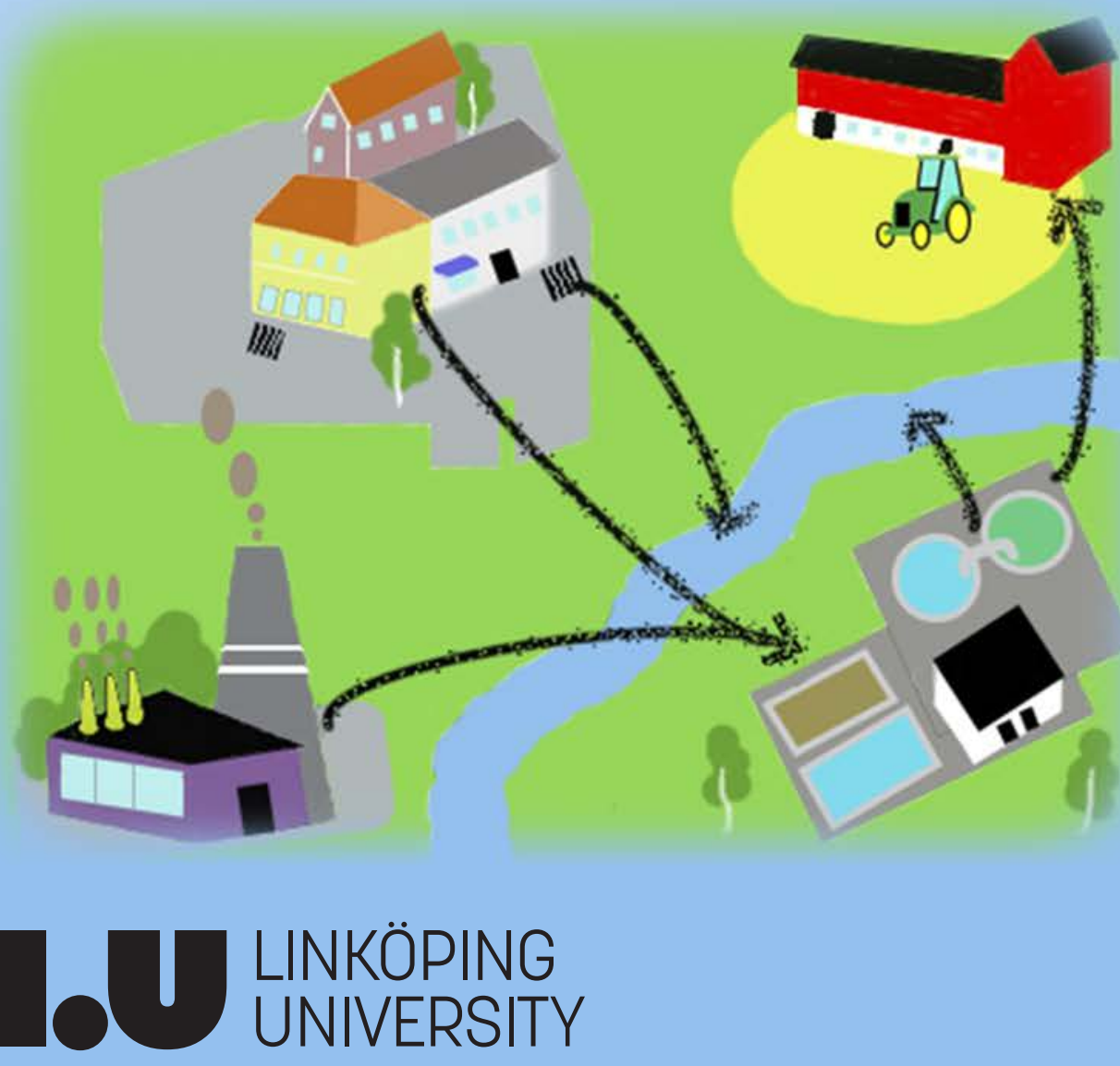





\title{
Towards the Control of Microplastic Pollution in Urban Waters
}

\author{
Emma Fältström
}

Environmental Technology and Management

Department of Management and Engineering Linköping University, SE-581 83 Linköping, Sweden. 
CEmma Fältström, 2020

Towards the Control of Microplastic Pollution in Urban Waters

Linköping Studies in Science and Technology

Licentiate Thesis No. 1888

ISBN: 978-91-7929-761-9

ISSN: 0280-7971

Printed by LiU-Tryck, Linköping, 2020

Cover design: Daniel Boström

Distributed by:

Linköping University

Department of Management and Engineering

SE-581 83 Linköping, Sweden. 
Science and everyday life cannot and should not be separated - Rosalind Franklin 



\section{Abstract}

Water pollution has long been considered a challenge in urban areas, and new types of pollution are continuously introduced to society. Urban wastewater and stormwater act as transport pathways of pollution from urban areas to receiving waterways. Microplastics are a new type of pollution that is being highlighted as problematic, and the presence of microplastics is widespread in the environment. The knowledge about behaviour, sources and transport pathways is still limited. Still, there have been suggestions for ways to control microplastic pollution. Moreover, many other pollutants have been introduced, and to a various extent controlled, in the urban water system before, which means that there are strategies for pollution control in place.

The problem of microplastic pollution is receiving attention from both research and policy. Therefore, there is a need to simultaneously explore ways to handle the pollution and learn more about the flows of microplastics. The aim of this thesis is to contribute to the understanding of flows of microplastics in urban waters and investigate strategies and measures that can control the flows. This aim has been addressed through three different studies presented in the three appended papers. The empirical material was gathered between 2017 and 2020 using both quantitative and qualitative methods. The flows of microplastics were investigated using a quantitative approach with inspiration from substance flow analysis. Strategies and measures to control pollution were investigated by means of analyses of documents, literature review and interviews.

In terms of flows, the results show that laundry seems to be a large contributor to the wastewater system, while the contribution from cigarette filters was smaller than anticipated. Littering, in general, as well as paint, are potentially important sources of microplastics where the understanding is very limited. In terms of strategies and measures to control the flows, there are both preventive and treatment options for microplastics. As microplastics are a diverse pollutant group, several different solutions are needed. Some aspects that influence control efforts are related to the properties and behaviour of the specific pollutant and can therefore be more or less suitable for different pollutants. Other aspects are more general, such as what compartments are seen as valuable and prioritised in terms of protection. Further, treatment moves the pollution from the water to another medium, and this movement also needs to be considered. 
Challenges in terms of changing, limited or even lack of legislation, as well as unclear responsibility, and problems with collaboration among urban actors also impact the possibilities to control pollution. The case of microplastics also raises questions about when and how pollution should be controlled and by whom. Further, emerging practices in the urban water system, such as source separation, pipe-separation, and water reuse, will have implications for how pollution will be handled in the future. 


\section{Acknowledgement}

My warmest thanks to...

... my supervisors. Stefan, I can always count on your insightful comments and honest critique. I learn something new every time we talk, and you are always there when I need advice. Sara, for asking the difficult questions and giving me new perspectives. HB, you always have an idea for a way forward when I feel stuck. And last but not least, Marinette. Thank you for believing in my abilities so much that you hired me without a project or a supervisor. I have learned so much from you, especially about what it means to be a good leader.

... all my colleagues, and I do have many! My everyday colleagues at NSVA who are always there to answer and discuss my weirdest and most detailed questions. To my travel partners Maja and Ellen, and all my other colleagues at Sweden Water Research. The encouragement from you guys during our weekly meetings means a lot. Thanks to my colleagues at the Division of Environmental Technology and Management. Although we do not see each other as often as I would like, I always feel very welcome at the division. Thanks for all the helpful feedback and all your help with everything, from understanding the printer to finding my way around campus.

... my mentor Magnus for the great conversations we have had the last year. You are an inspiration!

... all my friends, new and old, close, and far away; I am so lucky to have all of you! Lina, thanks for all your help and support. I miss you, and I am so sad that we did not get the chance to combat plastic pollution together!

... my family, by blood and by "association". My parents for your hospitality at my Linköping visits, equipped with lunch boxes, Friday whisky and support. Thanks also to my brother for your patient help with all computer-related questions and kind words. Karin, for encouraging me to take this chance and for listening to my frustrated rants about long review processes and rejections.

... most of all, Bosse and Melker. Thank you for everything! You are jättebäst! 


\section{List of appended papers}

Paper I: Fältström, E. \& Anderberg, S. (2020). Towards control strategies for microplastics in urban water. Published in: Environmental Science and Pollution Research, 27:40421-40433. https://doi.org/10.1007/s11356-020-10064-z

Contribution: The first author came up with the idea, developed the analytical framework, gathered most of the data and wrote the main part of the manuscript. The second author provided guidance in research design and wrote parts of the manuscript. The first author also had the main responsibility for the revision process.

Paper II: Fältström, E., Olesen, K.B. \& Anderberg, S. Microplastic types in the wastewater system - A comparison of calculation-based and measurementbased estimates. Submitted to Science of the Total Environment.

Contribution: The first author came up with the idea, carried out the theoretical analysis and wrote the manuscript. The second author reviewed the manuscript and performed sampling and analysis for the measured data. The third author assisted during the whole process and reviewed the manuscript.

Paper III: Fältström, E. \& Gustafsson, S. Upstream pollution control by water and wastewater utilities in Sweden - incentives and challenges. Draft, to be submitted to Water Policy

Contribution: The first author came up with the idea and research design together with the second author and the other supervisors. The first author collected and analysed the data and wrote the draft. 


\section{Related publications}

Related publication I: Fältström, E., Gustafsson, S., Hagman, M., Wittgren, HB. \& Anderberg, S. (2018). Kommunperspektiv på uppströmsarbete i Sverige idag och i framtiden. Rapport 2018-09. Stockholm, Sweden: Svenskt Vatten Utveckling.

Related publication II: Ljung, E. Olesen, K.B, Andersson, P-G., Fältström, E., Vollertsen, J., Wittgren, HB. \& Hagman, M. (2018). Mikroplaster i kretsloppet. Rapport 2018-13. Stockholm, Sweden: Svenskt Vatten Utveckling.

Related publication III: Ekblad, M. Fältström, E. \& Edefell, E. (2017). Reducing concentrations of microplastics and organic micropollutants - upstream and downstream abatement strategies. Conference Paper. $8^{\text {th }}$ International Young Water Professional Conference 2017 - Cape Town, South Africa.

Related publication IIII: Fältström, E. (2017) Uppströmsarbete: Detektivarbete för ett renare vatten. VATTEN - Journal of Water Management and Research 73:51-52. 2017 


\section{List of abbreviations}

CA cellulose acetate

CSO combined sewer overflow

EVA ethylene-vinyl acetate

PA polyamide

PE polyethylene

PES polyester

PLA polylactic acid

PP polypropylene

PU polyurethane

PVC polyvinylchloride

SFA substance flow analysis

WWTP wastewater treatment plant 


\section{Content}

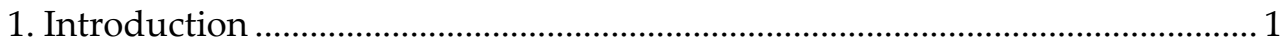

1.1 Aim and research questions ...................................................................... 3

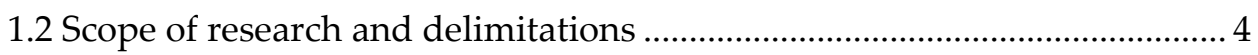

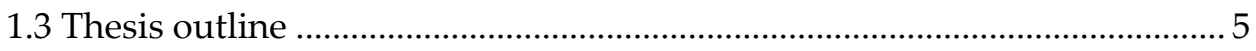

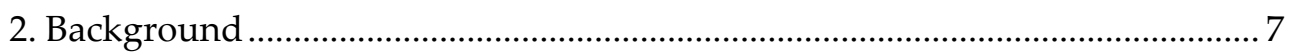

2.1 Pollution management of urban waters in Sweden ..................................... 7

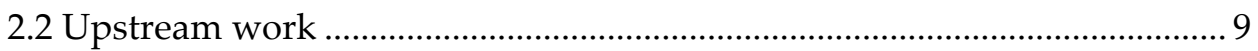

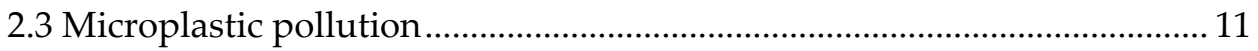

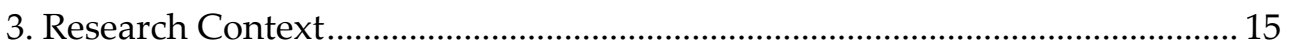

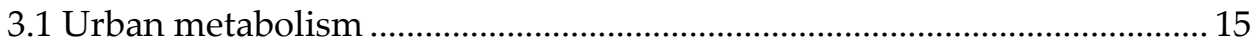

3.2 Environmental pollution in the urban water system ................................... 16

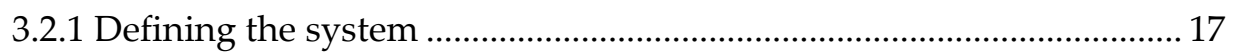

3.2.2 Types of strategies to control pollution in the urban water system ... 18

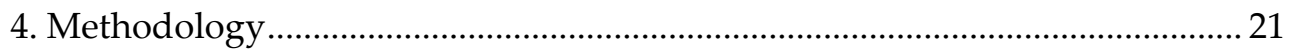

4.1 Reflections on the research journey ………………..................................... 21

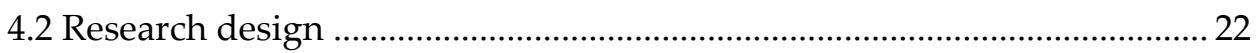

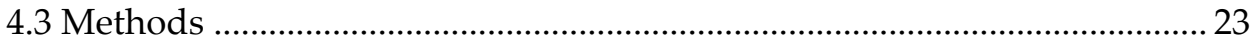

4.3.1 Paper I: Literature-based case analyses ................................................ 23

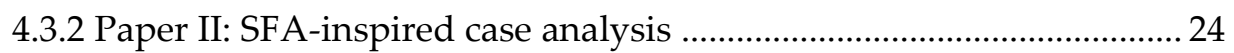

4.3.3 Paper III: Interview study prepared by survey ……............................. 25

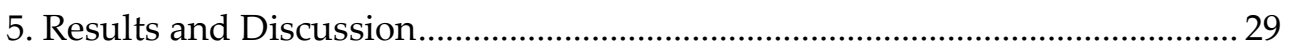

5.1 Flows of microplastics in urban waters....................................................... 29

5.2 Managing microplastics in urban waters....................................................... 32

5.2.1 Strategies and measures for microplastics in urban waters ................. 32

5.2.2 Considerations for the control of microplastics in urban waters........ 34

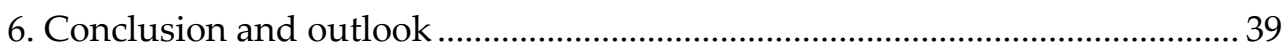

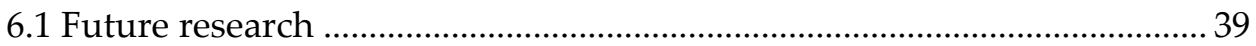

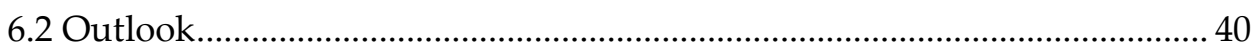

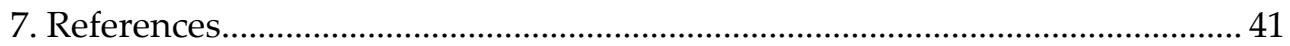




\section{List of Figures}

Figure 1: Relations between the three papers that form the basis of this thesis and the concepts it investigates.

Figure 2: Overview of important actors with regard to urban water pollution management in Sweden

Figure 3: Scientific and newspaper articles about microplastics and selected policy events .................................................................................................... 13

Figure 4: Overview of the studied system in this thesis ..................................... 17

Figure 5: Overview of the collection of empirical material for Paper III........... 27

Figure 6: Overview of the contribution of microplastics from household-, enterprise- and stormwater sources to Sjölunda WWTP.

Figure 7: A comparison of calculation-based estimates and measurementbased estimates of microplastic types

\section{List of Tables}

Table 1: Overview of the three papers and their relation to the research questions.

Table 2: Overview of the strategies and measures identified for microplastics, the type of strategy and the source for which the strategy or measure is aimed at controlling 


\section{Introduction}

This chapter introduces the topic of the thesis, and describes the aim and the research questions, as well as the context in which the research was conducted. The chapter ends with an outline of the rest of the thesis.

The importance of water and sanitation has been recognised in the $6^{\text {th }}$ sustainable development goal (United Nations, 2015). Securing enough drinking water, limiting the impacts of floods and handling wastewater are challenged by urbanisation, aging infrastructure, and population growth (Larsen et al., 2016). Further, the presence of pollution in the water impacts the possibility to achieve the sustainability goal and constitutes a threat to humans and the environment.

Environmental pollution can be defined as "the addition of any substance [...] to the environment at a faster rate than it can be dispersed, diluted, decomposed, recycled or stored in some harmless form" (Nathanson, 2020). This definition indicates that it is not only toxic substances that can be referred to as environmental pollution. Many essential substances, for example, nutrients or copper and zinc, can cause adverse effects when concentrations are too high. Other substances, such as cadmium, are not essential to humans or other organisms. However, cadmium flows are related to zinc production and mining of phosphate rock, which both are of societal importance (van der Voet et al., 1994).

Waterborne pollution in urban areas has a variety of sources, but a few groups can be distinguished. Releases from urban structures, such as buildings (Bollman et al., 2014; Sörme \& Lagerqvist, 2002), and urban activities, such as road traffic, cause pollution in stormwater. In addition, stormwater is also affected by atmospheric deposition of, for example, heavy metals (Bergbäck et al., 2001). Stormwater often receives no or limited treatment and is thus a transport pathway of many types of urban pollution to the receiving waters (Hvitved-Jacobsen et al., 2010).

Households and enterprises are the two main groups of sources for wastewater pollution. Households contribute with a variety of substances from the use of consumer goods (Amneklev et al., 2016; Luo et al., 2014; Villarín \& Merel, 2020). Enterprises such as dental practices (Sörme \& Lagerqvist, 2002), car washes (Bergbäck et al., 2001) and hospitals (Chèvre et al., 2013; Luo et al., 2014) also contribute to the pollution in wastewater. Urban wastewater can be treated at wastewater treatment plants (WWTPs). Modern WWTPs retain much of the 
organic material and nutrients in the wastewater. This is retained in the sludge fraction, which can be used as a fertiliser. However, the sludge also contains undesirable substances, such as heavy metals (Davis, 2010). Some substances, for example, many pharmaceuticals, are instead poorly retained at WWTPs and reach the receiving waters (Luo et al., 2014).

An alternative to end-of-pipe treatment is to control the pollution closer to the source. One such practice used in Sweden is called "upstream work" (Uppströmsarbete). Upstream work concerns efforts to prevent harmful substances, litter, and other types of pollution at source to avoid introduction to the water cycle (Swedish Water and Wastewater Association, 2017). Upstream work can be executed on different levels. Nationally, the central organisation for water and wastewater operators in Sweden, the Swedish Water and Wastewater Association, works for substitution of harmful substances, more stringent laws and regulations regarding pollution and information to households (Swedish Water and Wastewater Association, 2017). Yet, most of the upstream work is carried out locally by the water and wastewater utilities. This work is primarily aimed at controlling emissions of undesirable substances from enterprises connected to the WWTP (Fältström et al., 2018).

When new substances are recognised as problems, the knowledge about potential effects, sources, pathways, and abatement options is often limited. That there can be many emission sources further complicates the control of the pollution. In general, since the 1970s, industries have been increasingly controlled, which has increased the relative importance of diffuse emissions (Anderberg \& Stigliani, 1994). Diffuse emissions are both more difficult to identify and control compared to point sources (Revitt et al., 2013). Further, with the increasing control of industries, the relative importance of households as polluters is increasing (Swedish Water and Wastewater Association, 2017).

One type of pollution that has been highlighted as problematic is microplastics. These small plastic particles $(<5 \mathrm{~mm})$ are found in various marine (Cole et al., 2011) and freshwater environments ( $\mathrm{Li}$ et al., 2018). Microplastics are omnipresent in urban areas (Tibbetts et al., 2018) and occur in wastewater (Habib et al., 2020; Ngo et al., 2019) and stormwater (Liu et al., 2019; Olesen et al., 2019). Physical, behavioural, and reproductive effects on biota have been reported. However, there is a disparity between the most common polymers and shapes found in environmental samples and those used in ecotoxicological laboratory studies, as well as differences in concentrations used, which makes the environmental effects uncertain (de Sá et al., 2018). 
Increasing the knowledge about sources and pathways of microplastics has been identified as a key issue for upcoming research (Tumlin, 2017), but there are some challenges related to understanding the flows of microplastics. First, even if the research has grown rapidly, data is still limited and uncertain (Li et al., 2018). The data that does exist is often incomparable, as there are no standardised methods for neither sampling nor analysis. Concern has also been raised that some of the analytical methods used are subject to large uncertainties, and methods that have been highlighted as more reliable are timeconsuming and expensive (Koelmans et al., 2019; Li et al., 2018; Shim et al., 2017). Second, microplastics are a diverse group of substances consisting of many different polymers with different properties, potential sources, and pathways (Magnusson et al., 2016).

\subsection{Aim and research questions}

Microplastics are a new type of pollution, and although the research is growing rapidly, there is still limited knowledge, both related to the flows and environmental effects. Despite the uncertainties, microplastics have been subject to several policy interventions and, therefore, there is a need to simultaneously explore ways to handle the pollution and learn more about the flows of microplastics. The aim of this thesis is to contribute to the understanding of flows of microplastics in urban waters and investigate strategies and measures that can control the flows. In order to fulfil this aim, I have two research questions (RQs):

RQ1: What major sources of microplastics can be identified and verified in urban waters?

The first step in this research is to get a preliminary overview of microplastics flows in urban waters and to identify large flows as well as flows that are largely unknown and possibly need additional attention. Due to the uncertainties related to microplastics, this research also tests an approach to verify the identified sources. The second step is to develop a preliminary overview of the potential strategies and measures that can be used for microplastics. This is investigated in RQ2:

RQ2: How can existing pollution control strategies and measures, such as upstream work, give insights to the control of microplastics in urban waters?

Several efforts, both as more overall plans (referred to as strategies) and more concrete actions (referred to as measures), have been suggested to control the pollution from microplastics, and these need to be systematically organised. In 
addition, to further the understanding of possibilities and challenges for controlling microplastic pollution in urban waters, microplastics are related to existing practices in urban water pollution management.

\subsection{Scope of research and delimitations}

This thesis has two focus areas: flows of microplastics and control efforts, with special attention to upstream work. Microplastics are addressed in the first and the second paper. In Paper I, strategies and measures to control microplastics are discussed by building on insights from the management of three other pollutants present in urban waters (cadmium, copper, and pharmaceuticals). Paper II focuses on the flows of microplastics to a WWTP in Malmö, Sweden, and uses the results of upstream work as a method for data collection. Finally, Paper III focuses on upstream work as a strategy, specifically its incentives and challenges. Figure 1 shows the relationship between the papers that the topics addressed in this thesis.

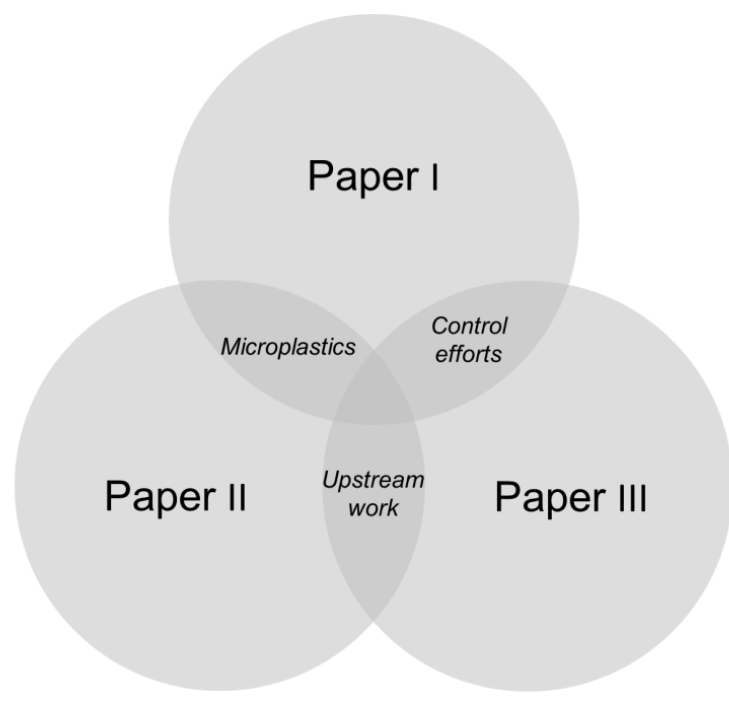

Figure 1: Relations between the three papers that form the basis of this thesis and the concepts it investigates.

This thesis focuses on microplastics in wastewater and stormwater in the Swedish context. Drinking water is also an important part of the urban water management system and can contain microplastics, but in terms of legislation, possible control efforts, health and environmental effects, and emissions sources, drinking water has large differences in comparison to stormwater and wastewater. The first paper includes both stormwater and wastewater, while the other two papers focus on wastewater. This has practical reasons. The 
understanding of microplastics is limited in general, but wastewater is somewhat more researched than stormwater, which is why it was the focus of Paper II. Stormwater is still addressed as part of the inflow and infiltration to the WWTP. Upstream work targeting wastewater is the most widespread and developed, and therefore it was the focus of Paper III.

There are practical reasons that Swedish conditions are in focus, in terms of access to contacts and a network in Sweden. Moreover, in the context of urban water services, Sweden has a developed system regarding, for example, pipebound infrastructure and amount of wastewater treated, like large parts of Europe (Larsen et al., 2016). Further, sewage sludge application on agricultural land is in Sweden, as in Europe in general, the most common form of sludge disposal (Hudcová et al., 2019; Statistics Sweden, 2020). However, the dominant sludge disposal route can largely differ between countries, and several aspects interact, such as access to agricultural land, amount of sludge generated, national limit values for sludge quality, as well as values and opinions among involved actors (European Commission, 2001; Hudcová et al., 2019; Statens offentliga utredningar, 2020). Sweden has, along with, for example, Denmark, made efforts to increase sludge quality to achieve acceptance for sewage sludge on agricultural land (Fältström et al., 2018; Jensen \& Jepsen, 2005).

\subsection{Thesis outline}

The thesis consists of three papers and an introductory essay. This essay consists of six chapters, of which this first one introduced the problem area, aim and research questions, and scope. The second chapter provides a background to the topic of this thesis. The purpose of this chapter is to give the reader a more detailed background to pollution management in Sweden and pollution from microplastics. The theoretical basis and a description of the system studied is presented in Chapter 3, research context. The methodology is introduced in Chapter 4, starting with reflections on the research journey, followed by the research design. After, the methods used for the three appended papers are presented. The results are presented and discussed in Chapter 5, and last, the conclusions drawn from this thesis are presented (Chapter 6). This chapter also raises future research possibilities stemming from the findings in this thesis and reflects on the future management of pollution in a changing urban water system. 


\section{Background}

This chapter describes urban water pollution management in Sweden, focusing on the role of water and wastewater utilities. Of the pollution control efforts by water and wastewater utilities, particular attention is paid to describing upstream work. The last part of this chapter is dedicated to the pollution of interest in this thesis, microplastics.

\subsection{Pollution management of urban waters in Sweden}

Municipalities have the main responsibility for handling stormwater and wastewater in Sweden. The water and wastewater utilities can either be organised within the municipality or as a cooperation between several municipalities (Thomasson, 2013; 2015). The environmental department at the municipality is responsible for controlling the enterprises in the municipality. For large enterprises, the county administrative board is instead responsible, but this responsibility can be allocated to the municipal level (Statens offentliga utredningar, 2020). It should be clarified that WWTPs also are considered enterprises and are subject to control by the county administrative board or environmental department at the municipality. An overview of important actors in relation to urban water pollution management is shown in Figure 2. The focus of this thesis is on the lowest level in Figure 2 - the municipal level.

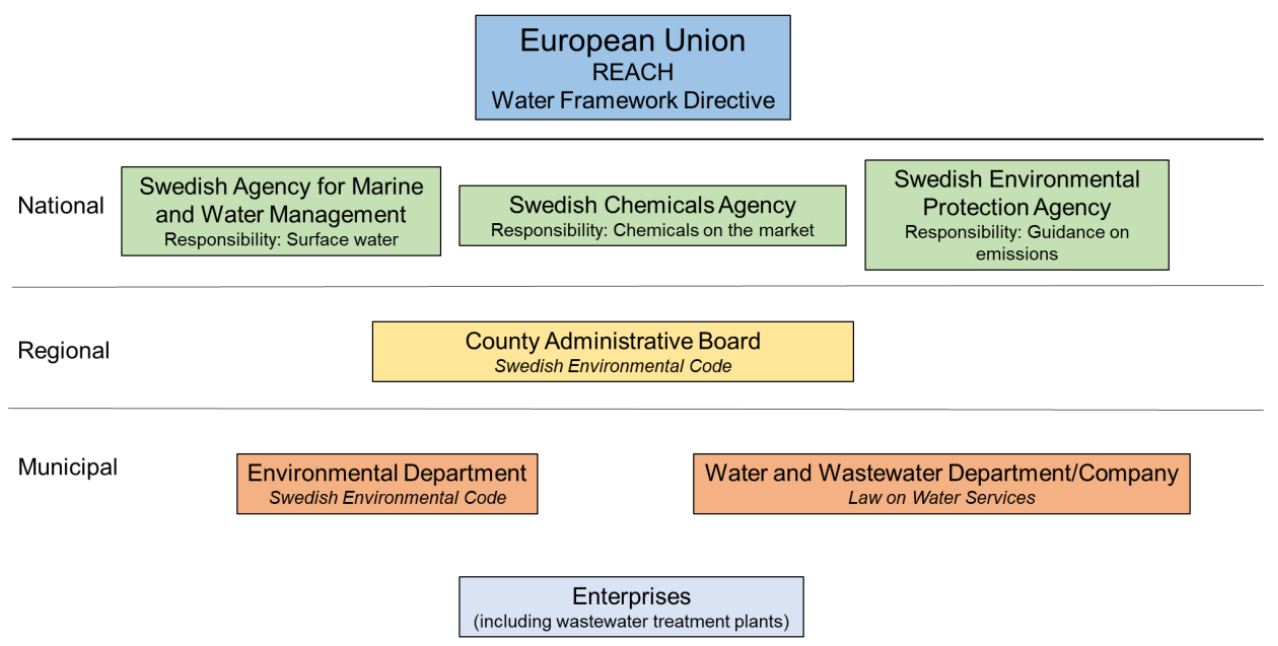

Figure 2: Overview of important actors with regard to urban water pollution management in Sweden.

Two laws are of primary importance for urban pollution control in Sweden: the Swedish Environmental Code (Miljöbalken (SFS 1998:808)) and the Law on Water Services (Lagen om allmänna vattentjänster (SFS 2006:412)). The Swedish 
Environmental Code is a regulative framework that integrates all environmental legislation with the aim of fostering sustainable development. The law, for example, regulates the responsibilities of the local and regional authorities to assure environmental and water quality and to control the activities of enterprises.

The Law on Water Services regulates the responsibilities related to water provision and use. WWTPs are only obligated to accept wastewater that resembles household quality. In practice, this means that the water and wastewater utilities can demand a certain water quality from connected enterprises before the water is released to the WWTP but cannot demand a certain type of treatment. Water and wastewater utilities have the possibility to specify limit values of specific substances or other parameters that may harm the pipe system, treatment processes, or affect sludge or water quality. Specific arrangements can also be made with individual industries regarding releases that deviate from the characteristics of household wastewater or regarding large water volumes (Swedish Water and Wastewater Association, 2019). The Swedish Environmental Code and the Law on Water Services are applied in parallel, and enterprises (including WWTPs) should follow both. The water and wastewater utilities can give restrictions to an enterprise with reference to the Law on Water Services in addition to restrictions given by authorities with reference to the Environmental Code.

At the national level, there are primarily three authorities that impact pollution control. The Swedish Agency for Marine and Water Management has the main responsibility for surface water in Sweden. It is also responsible for small wastewater treatment facilities ( $<200$ population equivalents), whereas the Swedish Environmental Protection Agency (EPA) is responsible for WWTPs above 200 population equivalents. The Swedish EPA, therefore, is the authority that most directly influences water and wastewater utilities. The Swedish EPA decides on emission levels in the effluent of WWTPs and provides guidelines for stormwater pollution. The Swedish Chemicals Agency is responsible for the chemicals that are allowed in Sweden and monitors toxic compounds in products. In addition, the Swedish Water and Wastewater Association, although not part of the legal framework, is an important actor. The association provides guidance for water and wastewater utilities, for example, in relation to specific types of enterprises, and voices the sector's interests nationally and on a European level. Further, as Sweden is part of the European Union (EU), regulations through $\mathrm{REACH}$ and the Water Framework Directive are also implemented in the country. 
Compared to wastewater, the regulative measures for stormwater are less clear. Stormwater can, under certain conditions, be viewed as wastewater (Swedish EPA, 2017). There is not a specific law that focuses on stormwater, but several laws (the Planning and Building Act, Law on Water Services, and the Environmental Code) impact (Swedish EPA, 2017). Further, the Water Framework Directive states that the quality of surface waters should not be degraded. Stormwater is an important contributor of pollution to surface water, which is why, in extension, stormwater pollution is also related to the Water Framework Directive. In Sweden, $8 \%$ of the stormwater is treated, $4 \%$ at WWTPs and the other $4 \%$ in stormwater treatment facilities (Swedish EPA, 2016). In other words, most of the stormwater reaches waterways without treatment.

Enterprises and property owners are responsible for the stormwater from their premises and should provide treatment if needed. However, if and where treatment should be required is difficult to determine. There are technical issues regarding how to measure and assess pollution impacts. In addition, it can be difficult to determine from which facility the polluted stormwater originates (Swedish EPA, 2017). The municipality can impact stormwater quality from the role of community planner, local regulatory authority, water and wastewater responsible, landowner, and operator. Stormwater management may also require collaboration between municipalities.

The specific responsibility of water and wastewater utilities for stormwater quality is unclear (Swedish EPA, 2017). As there is no "household-character" established for stormwater compared to wastewater, there is no reference value to compare pollution levels against. There have been research efforts to establish a pollution level in stormwater that is considered normal and which, therefore, should be the responsibility of the water and wastewater utility (Hjelmqvist et al., 2017). Water and wastewater utilities can establish stormwater plans with target values for things such as nutrients and heavy metals. The plans are passed by the city council but are not legally binding. Instead, they function as guidelines.

\subsection{Upstream work}

The work that is today referred to as upstream work was initiated in the early 1960s in Sweden. In the beginning, the primary aim was to protect the pipe system and the treatment processes from harmful substances. In the 1990s, upstream work was put forward as important for sludge quality. Today, upstream work consists of many different tasks. Mapping enterprises and 
requiring lists of chemical usage from enterprises are common practices, as well as information and visits to the connected enterprises. Water and wastewater utilities can also assist authorities in the formulation of legal permits for enterprises, but it is the local or regional authorities that give permits and make the final decisions. Sampling in the pipe system to find sources of pollution is also performed as part of the upstream work (Fältström et al., 2018).

Sludge management has long been subject to debate in Sweden (Bengtsson \& Tillman, 2004; Dagerskog \& Olsson, 2020). In 2018, 39\% of the generated sludge was used as fertiliser on agricultural land in Sweden. This makes fertiliser the most common form of sewage sludge application in Sweden (Statistics Sweden, 2020). The European sludge directive (86/278/EEC) is implemented in Sweden, but Sweden has, like many other European countries, also stricter national limit values (Hudcová et al., 2019). In addition, there is a voluntary certification scheme called Revaq that certifies WWTPs and has, for some parameters, stricter limit values than what is legally required (Malmqvist et al., 2006). The work towards a certification scheme started in 2002, and the first WWTP was certified in 2008. By the end of 2018, approximately 50\% of the sewage sludge produced in Sweden was from a Revaq-certified WWTP (Revaq, 2019). Systematic upstream work is a core requirement of Revaq. In practice, this, for example, requires that the WWTP monitor substances at inlet and select priority pollutants. Cadmium is always a prioritised pollutant, and if above a certain level, lead and mercury must also be included (Revaq, 2020).

In 2013, the Swedish EPA recommended the Swedish government to develop legislation that ensured that WWTPs performed upstream work. The suggested upstream work was similar to that of the Revaq certification (Swedish EPA, 2013). In 2018, a new inquiry was established with the aim to investigate a ban on sludge use while still recovering phosphorus from the sludge and ensuring the continuation of upstream work. In January 2020, the inquiry reported two suggestions to the government: 1) a complete ban of sewage sludge reuse, or 2) a ban with the exception of the application of high-quality sludge on productive land (Statens offentliga utredningar, 2020). The inquiry pointed to the risk that some incentives for upstream work will be reduced following a complete ban. Similarly, the Stockholm Environment Institute predicts that it would put an end to upstream work, such as under the Revaq certification (Dagerskog \& Olsson, 2020). 


\subsection{Microplastic pollution}

Microplastics are commonly defined as plastic particles smaller than $5 \mathrm{~mm}$ (GESAMP, 2015), which was decided at a conference in 2008 (Arthur et al., 2009). The lower limit is often set, due to analytical restrictions, at 10-20 $\mu \mathrm{m}$. There is, at this point, not a clear definition of what constitutes microplastics. Hartmann et al. (2019) propose a framework for defining plastic debris consisting of both defining and classifying criteria. Based on this framework, microplastics can be defined as synthetic polymers (included are considerably modified natural polymers such as rayon) that are solid and insoluble in water. Further, rubber from tyre wear is often included as a type of microplastic pollution (Hartmann et al., 2019). Microplastics (and larger plastic items) can also be classified according to size (nanoplastics, microplastics, mesoplastics or macroplastics), shape (fragment, fibre, sphere, film, etc.), colour, and origin. Origin refers to the separation of microplastics into "primary" and "secondary", dependent on if they are manufactured below a size of $5 \mathrm{~mm}$ or fragmented into a size below $5 \mathrm{~mm}$. Environmental non-degradability is sometimes also included in the definition of microplastics (see Amec Foster Wheeler, 2017), but Hartmann et al. (2019) propose that microplastics consisting of degradable polymers should also be considered.

There are no standardised methods for sampling and analysis of microplastics yet (Koelmans et al., 2019; Li et al., 2018; Oluniyi Solomon \& Palanisami, 2016; Vandermeersch et al., 2015). In the initial stages of this research field, particles were typically counted in a microscope (Hidalgo-Ruz et al., 2012), but concern have been raised about this method. Specifically, the method is subject to a significant amount of uncertainty with regard to the determination of a particle as plastic (Li et al., 2018). Methods that detect polymer type, such as Fourier Transform Infra-Red spectroscopy, can alleviate this problem. However, this method cannot detect car tyre rubber, which is why pyrolysis combined with gas chromatography-mass spectrometry is needed to detect such particles (Unice et al., 2013).

Microplastics are found in marine (Cole et al., 2011) and freshwater environments (Li et al., 2018), on shorelines (Browne et al., 2011) and even in remote areas such as the Arctic (Lusher et al., 2015). Microplastics are found in both marine and freshwater biota (Eerkes-Medrano et al., 2015), including organisms aimed for human consumption (Rochman et al., 2015). Humans are also exposed to microplastics through inhalation (Vianello et al., 2019) and drinking water (Koelmans et al., 2019). 
The sources of microplastics to the marine environment have been quantified in several countries, including Sweden (Magnusson et al., 2016). Activities in the ocean can give rise to microplastics, but the land-based sources dominate. Among large sources of microplastics are road traffic (Kole et al., 2017; Unice et al., 2013) and production spill (Karlsson et al., 2018). Insufficient waste management can also give rise to large quantities of plastic waste that can fragment into microplastics (Jambeck et al., 2015). Atmospheric deposition is a source that affects both land and water (Wright et al., 2020).

Specific sources of microplastics to wastewater are personal care products (Napper et al., 2015), dust (Dris et al., 2017), and the washing of synthetic textiles (Browne et al., 2011; De Falco et al., 2018). The retention capacity of microplastics at WWTPs is often around $90 \%$ and sometimes even up to $99 \%$ (Habib et al., 2020; Hu et al., 2019; Sun et al., 2019). Still, elevated levels of microplastics have been reported in wastewater recipients (Estahbanati \& Fahrenfeld, 2016). Microplastics are found in the sludge fraction but are also removed in earlier treatment steps, which can be incinerated (Murphy et al., 2016). The application of sewage sludge on agricultural land has been put forward as a potential pathway of microplastics to the terrestrial environment (Nizzetto et al., 2016), but when compared to soil fertilised with mineral fertiliser, the microplastic content was similar unless high quantities of sludge were applied (Ljung et al., 2018). Other sources of microplastics in the soil can be plastic mulching, littering, irrigation and flooding, and atmospheric deposition (Bläsing \& Amelung, 2018).

Large sources of microplastics to stormwater are, for example, road traffic, artificial turfs (Kole et al., 2017) and paint (Verschoor et al., 2016). Microplastics have been found in stormwater from a variety of urban catchments, such as residential areas, industrial and commercial sites and highways (Liu et al., 2019). In stormwater ponds, the majority of the microplastics were found in the sediments, followed by biota, and the least was found in the water (Olesen et al., 2019), which indicate that stormwater retention ponds retain microplastics.

Microplastics have rather recently received attention and concern as a pollution problem (Thompson et al., 2004), but the interest is growing rapidly (Blettler et al., 2018). A search for the keyword "microplastics" in the Scopus database generated two scientific publications in 2009 and 942 publications in 2019. The issue has also received media and policy attention in Sweden (Figure 3). 


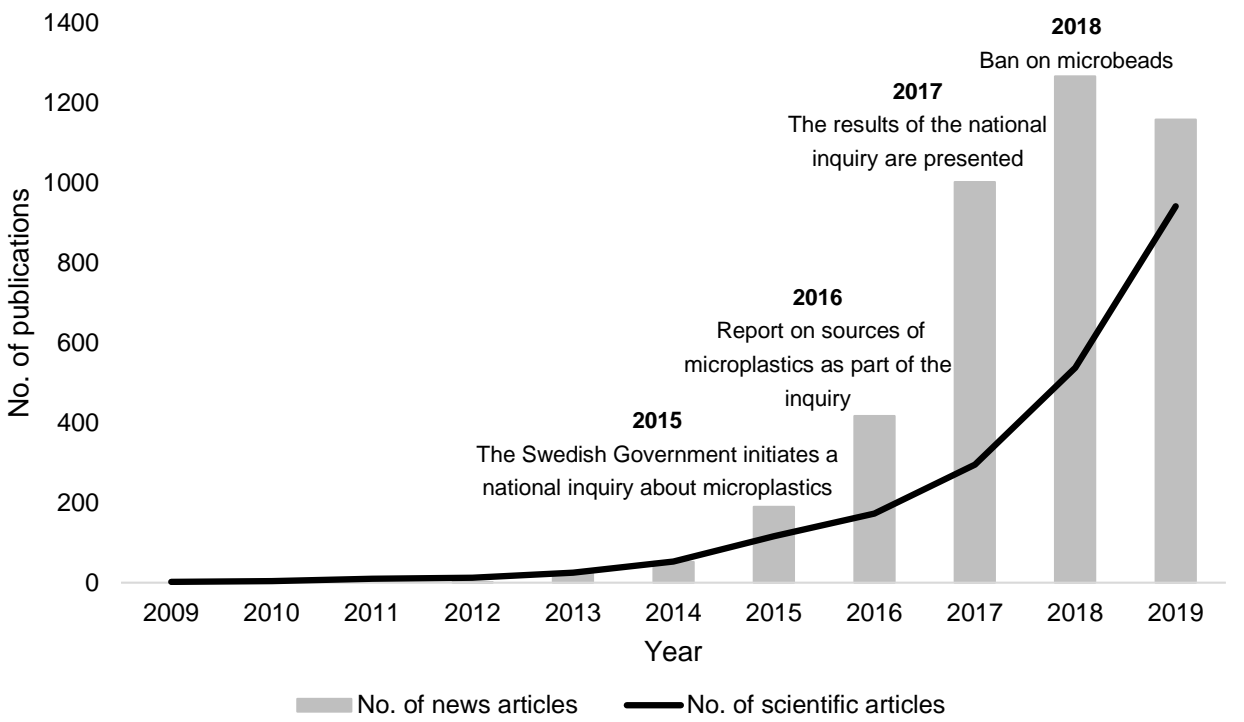

Figure 3: Scientific and newspaper articles about microplastics and selected policy events. Number of articles per year between 2009 and 2019 for the search term "microplastics" in the Scopus database (black line) and number of articles in Swedish newspapers per year between $2009^{1}$ and 2019 for the search term "mikroplaster" (grey bars) (National Library of Sweden, n.d.). The figure also shows selected policy events in Sweden.

Microplastics are seldom targeted in specific legislation (Pettipas et al., 2016). One exception is the case of microbeads in personal care products, which has been legislated in several countries (Xanthos \& Walker, 2017). In Sweden, plastic microbeads were banned in personal care products that are rinsed off in 2018 (Swedish Chemicals Agency, 2020). Legislation on microbeads has been criticised for only addressing a rather small source, and there have been problems both when excluding and including biodegradable plastics in the legislation (McDevitt et al. 2017).

\footnotetext{
${ }^{1}$ From 2014 and onward, all Swedish newspapers are included in the database. Before 2014, a selection of newspapers was included.
} 


\section{Research Context}

This chapter presents the theories and concepts used in this thesis. The chapter starts with a description of the theoretical foundation, urban metabolism. Urban metabolism was seen as suitable as it depicts flows in urban systems and the transformation of these flows within the system. After, the urban water system is introduced and defined in relation to this thesis. Both technical and management aspects of the system are highlighted from a pollution perspective.

\subsection{Urban metabolism}

Urban metabolism is a concept to model and analyse urban systems. It can be defined as "the sum total of the technical and socioeconomic processes that occur in cities, resulting in growth, production of energy, and elimination of waste" (Kennedy et al., 2007, p.44). In other words, urban metabolism concerns the quantification of input, output and storage of energy, water, nutrients, materials and wastes for a defined urban system (Kennedy et al., 2011). In practice, flows of a particular material or even specific substances are also investigated (Beloin-Saint-Pierre et al., 2017). Urban metabolism deals with the transformation of fuel, food and water (Decker et al., 2000). Water does not behave as fuel or food in an urban system because it can be purified and reused before it leaves the urban system (Decker et al., 2000).

The concept of urban metabolism is found in the field of Industrial Ecology. The first urban metabolism study is thought to be Theodor Weyl's work "Essay on the metabolism of Berlin" from 1894, where he quantified the consumption of water, food and nutrients and the export of water and nutrients through the sewer system for Berlin (Lederer \& Kral, 2015). Another key study using urban metabolism is that of Wolman (1965), who investigated a hypothetical American city. Wolman (1965) identified three metabolic problems: adequate water supply, the effective disposal of sewage and the control of air pollution and quantified three inputs (water, food and fuel) and three outputs (sewage, solid refuse and air pollutants) in the hypothetical city. As seen in these two examples, water is a key issue in urban metabolism studies. Further, one of the core ideas in the development of urban metabolism was the transfer of nutrients in sewage sludge from urban areas back to agricultural land (Barles, 2010). This is an issue that is still debated today (Paper III).

There are several tools for quantifying flows in urban metabolism studies. For environmental pollution, substance flow analysis (SFA) has been particularly useful. The difference between material flow analysis (MFA) and SFA is that MFAs quantify stocks and flows of material (Kennedy et al., 2011) while SFAs 
focus on a substance or substance group, for example, heavy metals or nutrients (van der Voet, 2002). SFA has been put forward as useful for environmental protection in general (Brunner, 2012) and urban water management (Chèvre et al., 2011) and upstream work (Amneklev, 2015) in particular.

One can distinguish between two different approaches for data collection in urban metabolism studies, top-down and bottom-up (Beloin-Saint-Pierre et al., 2017). In top-down studies, national statistics are used for estimating the flows of, for example, a city within the country. Bottom-up data is instead obtained from the system studied, via field measurements, inventories, and estimations of different activities in the city, or proxies from comparable systems. It is also possible to use top-down data for some flows and bottom-up data for other flows within one study. The choice of approach is often related to data availability (Beloin-Saint-Pierre et al., 2017). The availability and quality of data may substantially differ between substances and regions. Further, data on some flows for one substance may be more uncertain and less studied than other flows for the same substance (Amneklev, 2015; Laner et al., 2014). Often, a variety of different types of data from different sources are used, such as national statistics, expert judgements and "educated guesses" (Laner et al., 2015).

\subsection{Environmental pollution in the urban water system}

"Systems are made up of sets of components that work together for the overall objective of the whole. The systems approach is simply a way of thinking about these total systems and their components" (Churchman, 1968, pp. 11). From this definition, one can withdraw some common characteristics of a system. A system consists of components that are interconnected, and the system has an overall function or purpose. An important aspect when engaging in systems research is defining what should be considered part of the system and what lies outside of the system and should be considered belonging to the environment (Olsson \& Sjöstedt, 2005). Aspects of the environment can influence the system, but the system cannot alter these aspects (Churchman, 1968). The line between the system studied and the environment is referred to as the system boundary. The system boundary should be carefully set and transparently described (Brunner \& Rechberger, 2004). Setting too narrow boundaries might exclude important components of the system and, for example, lead actors to deploy measures that have negative effects in other parts of the system. However, with too wide system boundaries, the system can be too complex to overview (Meadows, 2008). 


\subsubsection{Defining the system}

The system that is investigated in this thesis is described in Figure 4. Following the concept of urban metabolism, the input to the system is drinking water and rainwater or snow, which through the processes within the system is transformed into polluted wastewater and stormwater. Re-use of treated wastewater for drinking water purposes is not considered in this thesis since it does not occur in Sweden.

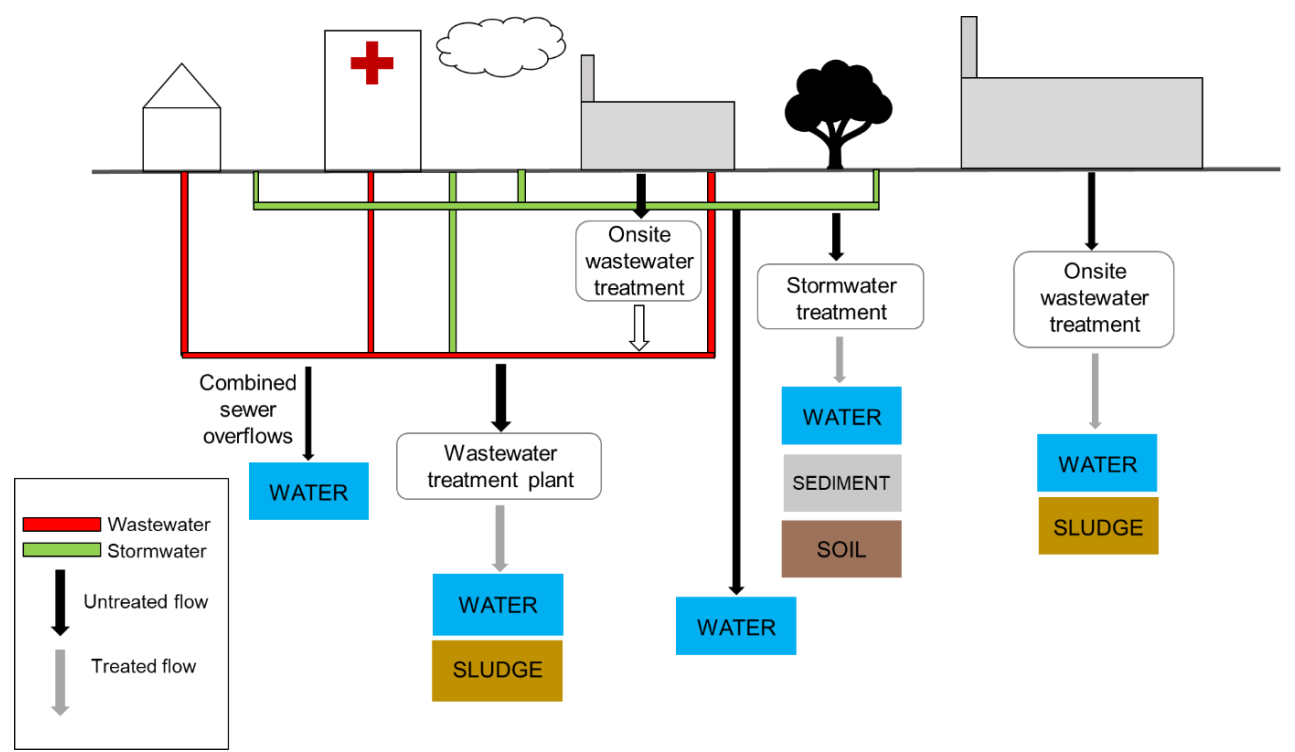

Figure 4: Overview of the studied system in this thesis. Developed from Revitt et al. (2013) and reproduced from Paper I.

The transformation from drinking water to wastewater typically takes place in households and enterprises. Some enterprises may have their own treatment facilities and not be connected to the WWTP. Other enterprises may have their own treatment before releasing water to the WWTP, or they release directly for treatment at the WWTP. Urban activities such as traffic and urban structures, for example, roofs and facades, transform rain or snow into polluted stormwater.

About $13 \%$ of the pipe system in Sweden consists of combined sewers (Swedish Water and Wastewater Association, 2016). Combined sewers collect both wastewater and stormwater, which is transported to the WWTP. On the occasion of heavy rain, the capacity of the pipes can be exceeded, and untreated or partially treated water is released to recipients. This is referred to as combined sewer overflows. 
Treatment produces by-products, and treatment processes re-distribute the pollution from water to the sludge or sediment during treatment or retention. The receiving compartments considered in this thesis are water, sludge, sediment, and soil (Figure 4). The pollution might spread further if sewage sludge is applied to agricultural soils or if cleaned-out sediments are placed on soil, resulting in uptake or leakage back to the water. The treatment utilised at WWTPs or stormwater facilities does not retain $100 \%$ of the pollution entering the treatment facility, which is why water is an important compartment also after treatment.

Factors such as precipitation, percolation, and binding of pollution in soil, sludge and sediment, which has to do with the physical properties of the pollution in question, are considered belonging to the environment. The inputs to the defined system in terms of the amount of drinking water used and transformed into wastewater are also considered part of the environment.

\subsubsection{Types of strategies to control pollution in the urban water system}

The conventional urban water management system in high-income countries is characterised by large technical solutions consisting of large, pipe-bound infrastructure and treatment facilities. These systems deliver the required services sufficiently but are subject to high investment costs, long planning times, and potential resources are not utilised efficiently (Larsen et al., 2016). Changes to the urban water system are, in general, slow (Kiparsky et al., 2013).

Specifically, for pollution problems, there are some challenges related to traditional urban water management. Treatment techniques move the pollution to different compartments within or outside of the urban system. This can lead to trade-offs. For example, Revitt et al. (2013) showed that a decrease in pollution in surface water, which is an objective in the Water Framework Directive, results in an increase of pollution in sewage sludge or stormwater sediments. In addition, the introduction of new types of primarily synthetic pollution, has increased in the last decades. These are typically not monitored nor regulated, and the conventional treatment processes are not designed to handle them (Nawaz \& Sengupta, 2019).

Eriksson et al. (2011) divide the strategies for urban pollutant control into preapplication (for example legislation), pre-release (treatment before receiving compartment for example at a WWTP) and post-release (measures after release into the urban environment, such as best management practices for stormwater treatment or street sweepings). However, with a focus on the water system, this 
division can cause confusion. From this perspective, pollution that enters the WWTP with wastewater is not seen as pre-application as it has entered the water. In a similar way, street sweepings can be seen as pre-application from the water perspective as it avoids the introduction of the substance to the water.

Treatment can be separated into decentralised and centralised, dependent on where in the system the treatment is placed. There are no clear definitions of what constitutes decentralised or centralised, but it is a sliding scale and dependent on the spatial viewpoint (Libralato et al., 2012). From a local perspective, decentralised treatment can be said to be the treatment placed close to the source at, for example, industrial facilities, hospitals, or households. Here, some stormwater treatment can also be included, such as in retention ponds or filters in stormwater wells. The centralised treatment is most often done at WWTPs. There can be benefits and drawbacks with both treatment options. If the treatment technology is expensive and there is a collection system in place, centralised treatment can be favourable. Decentralised treatment can be beneficial as more specialised techniques can be used and adapted to the specific characteristics of the water or a specific pollutant (Libralato et al., 2012).

Other strategies and measures that are not treatment can be called preventive as they prevent the pollution from entering the water. These are similar to what Eriksson et al. (2011) named pre-release and are the strategies and measures that inhibit the release of pollution to the water. Examples of such efforts are prohibition, substitution, and economic incentives, or other voluntary efforts. 


\section{Methodology}

This chapter presents the points of entry for my research and the journey towards this thesis, the overall research design, and the methods in the three papers that provide the basis for this thesis.

\subsection{Reflections on the research journey}

The research journey for this thesis started in 2016. I was at that point employed by the municipal water and wastewater utility Nordvästra Skånes Vatten och Avlopp (NSVA), which provides water and wastewater services for seven municipalities in north-western Scania. NSVA owns a research company called Sweden Water Research, together with two other water actors in western Scania (VA SYD and Sydvatten). My first task as a PhD candidate was to initiate a project on upstream work. I received financial means from the Swedish Water and Wastewater Association to give a first overview into the many ways upstream work is carried out in Swedish municipalities. This project resulted in Related Publication I, and the results from the project are partially presented in Paper III.

The same year as I started my doctorial research, the Swedish Environmental Institute (IVL) highlighted the issue of microplastics in a report (Magnusson et al., 2016), which considered both wastewater and stormwater as important pathways. As a representative from the water and wastewater utilities, I got to be involved in a project aimed at establishing a mass balance for microplastics at a WWTP by sampling the inlet, outlet, sludge and soil fertilised with sludge (Ljung et al., 2018). This project raised some new questions regarding microplastic flows. Over $60 \%$ of the microplastics found at the inlet was not accounted for in the mass balance. Further, soil fertilised with sewage sludge had almost the same concentration as soil fertilised with mineral fertiliser. The method, which was new at the time, also highlighted new questions related to polymer distribution. Sludge-fertilised soil had more plastic types than soil fertilised with mineral fertiliser, and a "fingerprint" in terms of plastic types from the sludge could be found in sludge-fertilised soil. This got me thinking about source tracking. Based on the insights from the above-mentioned project, I saw the opportunity to combine my interest in upstream work, substance flow methodology and microplastics. This work is presented in Paper II.

Being an industrial $\mathrm{PhD}$ candidate means that I am part of the system I study. This is positive in the sense that I find research topics and see research problems at work. This was the case with Paper I. The challenging part with being an industrial $\mathrm{PhD}$ candidate is that problems often need to be solved rather 
urgently, and the research sometimes feels too slow and too uncertain for the answers the industry requires. Further, as an industrial $\mathrm{PhD}$ candidate, it can be challenging to differentiate between the role of a researcher and the role of an employee, and the two roles must be communicated in all forms of contact.

In the development of this thesis, aspects related to a transdisciplinary research approach have been used. This specifically regards stakeholder involvement throughout the research projects in the form of reference groups and experts. The stakeholders involved have mainly been from the water and wastewater sector, but also from the broader environmental sector. Transdisciplinary research approaches are advocated as a way of dealing with complex societal problems, which environmental pollution in urban waters entail, and to bridge the gap between science and policy (Thompson et al., 2017).

\subsection{Research design}

Two areas are investigated in this thesis: microplastics and pollution control, with special attention to upstream work. Both microplastics and upstream work can be considered new research areas but in different ways. Upstream work has been practiced since the 1960s in Sweden but has not been widely researched. Microplastics, on the other hand, is new in the sense that it has not been a research topic until the last decade, but since then, the research has grown rapidly (Figure 3). The main similarity between these two concepts is that they are not well-defined. Upstream work can include many different types of practices, and it can be a challenge that it is not defined (Paper III). Microplastics are often defined as plastic particles $<5 \mathrm{~mm}$, but it has been argued that a more rigorous definition is needed (Hartmann et al., 2019). This poses both challenges and opportunities and demands flexibility regarding research design.

This thesis builds on a system perspective and a flow perspective (see Chapter 3). From a flow perspective, an understanding of sources, pathways and receiving compartments is central to understanding where in the system efforts are possible and would be most effective (Brunner \& Rechberger, 2004). From a system perspective, the three papers focus on different parts of the system studied (see Figure 4). The first paper investigates the flows of pollution for the whole urban water system in terms of sources, pathways and receiving compartments. The second paper focuses on the flows to the WWTP (i.e., the red lines in Figure 4). The third paper focuses on the processes in place to control what is released to WWTPs. In other words, the third paper focuses on the point of the system where the enterprises and households connect to the wastewater system. Paper II is primarily used to answer RQ1, but Paper I gave a first 
understanding of flows (Table 1). Paper III, together with Paper I, provides the basis for answering RQ2.

Table 1: Overview of the three papers and their relation to the research questions. A large $X$ indicates that the paper was of high importance for answering the research question, while a small $\mathrm{x}$ indicates that the paper was used to answer the research question, but not to the same extent.

\begin{tabular}{|c|c|c|}
\hline & Research Question 1 & Research Question 2 \\
\hline Paper I & $\mathrm{x}$ & $\mathrm{X}$ \\
\hline Paper II & $\mathrm{X}$ & \\
\hline Paper III & & $\mathrm{X}$ \\
\hline
\end{tabular}

\subsection{Methods}

Several methods, both quantitative and qualitative, were used in this thesis project, and the method choices were made by focusing on different aspects of the research problem (Creswell, 2014). A quantitative method was deemed appropriate to investigate the flows of microplastics, and this investigation is inspired by SFA. For management-related aspects, a qualitative approach based on analysis of documents and interviews was used. In the following section, the methods used, the rationale behind the choices and the drawbacks and challenges are discussed for each of the three papers.

\subsubsection{Paper I: Literature-based case analyses}

In Paper I, three cases (cadmium in Stockholm, Sweden in 1995, copper in Vienna, Austria in 2013, and pharmaceuticals in Lausanne, Switzerland for an undefined year) were used for a comparison of flows, and strategies and measures to control the flows. Information related to the strategies and measures were gathered in 2018. Using multiple cases can be a springboard for reflections and contrasting findings (Bryman, 2016), which was how it was used in Paper I.

Three criteria were used for the selection of cases. First, the substances were to have negative environmental consequences. Second, the substances were selected based on differences between them, related to their properties, history, and use. This selection was made to increase the possibility to draw conclusions regarding strategies for microplastic pollution. Third, the substances were to be considered an environmental problem in urban waters. One scientific SFA study on a city level in a European context was chosen for each substance. The reason for choosing SFA studies was the possibility this tool has for receiving an overview of substance flows within a delimited system such as a city (Brunner, 2012). 
Information about pollution flows was derived directly from the SFAs. Scientific literature, EU directives and official documents were used to find information about the strategies and measures used in the three cities. When these documents did not provide sufficient information, contact with experts such as city officials was taken. The purpose of this analysis was to give insight into the specific contexts of the pollution management for the three substances in the three case cities.

The fact that the documents used in the research have been created outside the research process is both an advantage and a limitation. The advantage is that the documents have not been impacted by the research process. However, the documents might not be on the detail level that is desirable, or documents of importance may be difficult to access, while easily accessible documents might paint a biased picture (Bowen, 2009).

The cadmium study was carried out in Sweden, which made documents connected to this case more easily accessible. For the Swedish case, I also have more background knowledge into different opinions and debates in this area than for the other countries. This can give me a more diverse picture of the situation in Sweden than for the other countries. For example, the literature related to the implementation of pharmaceutical treatment gave a rather positive picture, but there might have been, and still be, interesting national and local discussions and critique that were not found. However, this would have been a larger issue if different strategies were to be evaluated based on feasibility and performance.

As Switzerland is at the forefront of pharmaceutical treatment, it has been subject to research published in scientific journals and even reports in Swedish. Copper in Austria provided the most challenges in terms of finding documents on strategies, primarily for the local level. Therefore, contact with city officials in the area was taken to receive more information and additional documents that had not otherwise been discovered or accessible. Further, as the co-author of this paper is fluent in German, we were not limited to documents written in English.

\subsubsection{Paper II: SFA-inspired case analysis}

In Paper II, Sjölunda WWTP is used as an example case. In accordance with Bryman (2016), I do not want to use the term representative case. While Sjölunda WWTP is representative in the sense that it has a mixture of wastewater from households, enterprises and inflow and infiltration, it cannot be said to be a representative for WWTPs in Sweden. Sjölunda WWTP is one of the largest 
WWTPs in the country (VA SYD, 2020b). Further, in Malmö, 35\% of the pipe system is combined (VA SYD, 2020a), which is higher than average in Sweden (Swedish Water and Wastewater Association, 2016). Combined sewers have been shown to increase the amount of microplastics at WWTPs (Sun et al., 2019).

The approach in this paper was inspired by the accounting procedure in SFA, which provides an overview of flows (van der Voet, 2002). This approach was chosen as, at this stage of microplastic research, achieving more and more detailed overviews is an important step forward. SFA is further often focused on a defined geographical area (Azapagic et al., 2007), which made it suitable for analysing flows to a specific WWTP. In this study, the potential sources of microplastic types ${ }^{2}$ that would end up at the WWTP were calculated and compared to estimates based on measurements of microplastics collected at the inlet of Sjölunda WWTP in 2017. Scientific literature, grey reports, national statistics, and environmental reports for Sjölunda WWTP were used as a basis for the calculation-based estimates. To estimate the load from enterprises, information from the management tool that VA SYD (which operates Sjölunda WWTP) uses to store information about enterprises was used to estimate the load. In this management tool, VA SYD can add notes from its contact with the enterprises. These notes gave additional information about enterprises that could be of importance for the assessment. This information is a result of the upstream work performed by VA SYD. If additional information was needed regarding a specific enterprise, the environmental department that performed control for the specific enterprise was contacted.

The largest challenge when conducting this study was the limited and sometimes even contradictory data. As noted by Amneklev (2015) as well as Laner et al. (2014), some flows for a certain substance are less investigated than others. For microplastics, knowledge is generally limited. Still, in relative terms, wastewater has been more addressed than stormwater, and the release of textiles has received more attention than paint or dust. However, studies on textile release show contradictory results. Taking such differences and uncertainties into account resulted in large intervals in the calculation-based estimates.

\subsubsection{Paper III: Interview study prepared by survey}

For Paper III, semi-structured interviews were conducted in 2017 with employees at water and wastewater utilities that had upstream work as their

\footnotetext{
${ }^{2}$ These were polymers that fulfil the definition of microplastics, that is, a size below $5 \mathrm{~mm}$, solid and insoluble in water.
} 
major task. The purpose of the interviews was to find incentives and challenges to upstream work as experienced by the practitioners. A survey was carried out targeting practitioners at water and wastewater utilities to prepare the interviews. The online survey had three purposes: 1 ) receive an overview of the status of the upstream work, 2) identify topics and questions for the interviews, and 3) select respondents for the interviews. The survey was answered by 44 organisations, representing 87 municipalities, which is $30 \%$ of the municipalities in Sweden ${ }^{3}$. Only one organisation that did not perform upstream work answered the survey. This respondent did not want to participate in an interview. Therefore, there is still a knowledge gap in terms of the lack of motivation for upstream work.

For the interviews, twelve respondents were selected. The primary focus of the selection was variation (Bryman, 2016), that is, to receive a representation of different types of organisations. The interviews were conducted over the phone. According to Bryman (2016), there do not seem to be any significant differences between face-to-face interviews and phone interviews in terms of data quality. However, when conducting phone interviews, non-verbal communication, such as body language and facial expression, is lost (Irvine et al., 2013). The importance of these non-verbal forms of expression depends on the research objective (Opdenakker, 2006), and for this research, the content rather than how it was expressed was of main importance. Still, when using phone interviews, there might be a need for more verbal acknowledgement expressions as well as sensitivity to verbal signs of confusion as non-verbal signs of confusion are lost (Irvine et al., 2013). Phone interviews were chosen as the respondents were widely spread over the country. Semi-structured interviews were chosen as this offers flexibility compared to structured interviews and structure to keep on topics related to the research interest compared to unstructured interviews (Bryman, 2016).

Regardless of whether the interviews are conducted face-to-face or over the phone, there is a risk that the researcher affects the data that is being collected in the interview process (Creswell, 2014). By being employed by a water and wastewater utility, I am familiar with the challenges and limitations of the sector, which may lead me to pick up on certain topics in a way I would probably not have done without my background knowledge. On the other hand, it might also have made me not pick up on topics that someone new to the field would highlight. For this project, I also had a reference group with

\footnotetext{
3 Sweden has 290 municipalities (Statistics Sweden, n.d.).
} 
experts in the field that influenced how the study was carried out. Their inputs made the study more comprehensive but also impacted what was raised in the survey and interviews.

Respondents can be affected by the researcher and study context. By being an industrial $\mathrm{PhD}$ candidate, the respondents might have viewed me more as a colleague than as a researcher. This can be positive for the interview situation, but it may also have affected how the respondents reflected on issues, and to someone outside the sector, they would perhaps have given more elaborate explanations. I tried to impede this by asking follow-up questions. Further, this study was financed by the Swedish Water and Wastewater Association, and the respondents knew that they could have access to the results in the form of a report (Related Publication I), which I believe was positive for the will to participate in the interviews. However, it might have led to more sector-specific issues being raised compared to if the interviews would have been performed in an academic context.

The interview material was thematically analysed using an analytical framework that was developed from literature on incentives and challenges from areas with similarities to upstream work. Inspiration was particularly found in research on emerging or non-traditional forms of management. Specifically, this concerned sustainable urban water management (Brown, 2005; Brown \& Farrelly, 2009) and sustainable waste management (Pollans, 2017; Wilson et al., 2001), experimental techniques and new forms of practices, such as onsite sewage treatment and reuse, and blue-green stormwater solutions (Farrelly \& Brown, 2011; Wihlborg et al., 2019). Figure 5 gives an overview of the research process for Paper III.

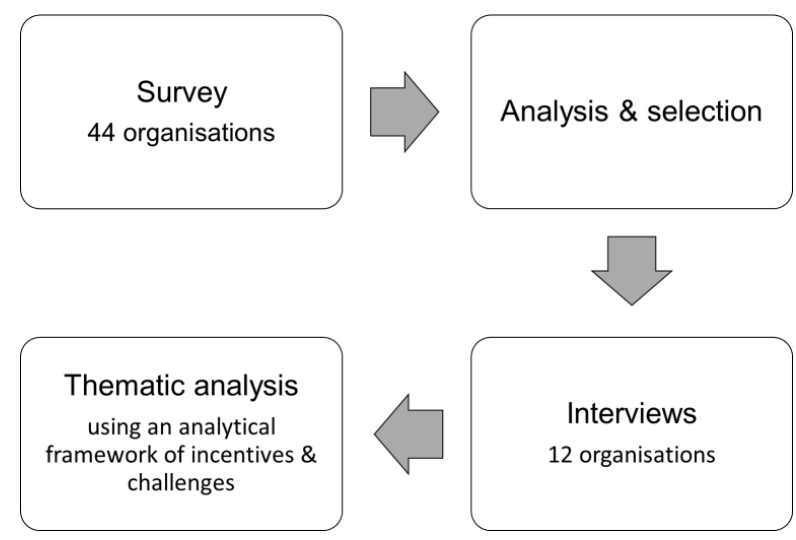

Figure 5: Overview of the collection of empirical material for Paper III. Reproduced from Paper III. 


\section{Results and Discussion}

In this chapter, the results are summarised, synthesised, interpreted and discussed. The chapter is structured by the two research questions posed in this thesis.

\subsection{Flows of microplastics in urban waters}

The research on microplastics is still at an early stage, and the understanding of sources and pathways is limited. RQ1 concerns the identification and verification of sources of microplastics in urban waters, which was particularly investigated in Paper II.

Pollution to a WWTP originates from two main groups of sources: households and connected enterprises. Sjölunda WWTP also has combined sewers, which means that stormwater is added to the WWTP. The calculation-based estimates to Sjölunda WWTP generated a microplastic load between 1.9 and 14 tonnes/year. The measurement-based estimates were at the lower end of this and estimated to 4.2 tonnes/year. Households stood for the largest share of the microplastic load to the WWTP (67-92\%), followed by stormwater (5-30\%) and enterprises (3\%) (Figure 6). If relating this to the water volumes at the WWTP in $2017,69 \%$ is estimated to be wastewater (of which $74 \%$ is from households), and the rest is inflow and infiltration (VA SYD, 2018).

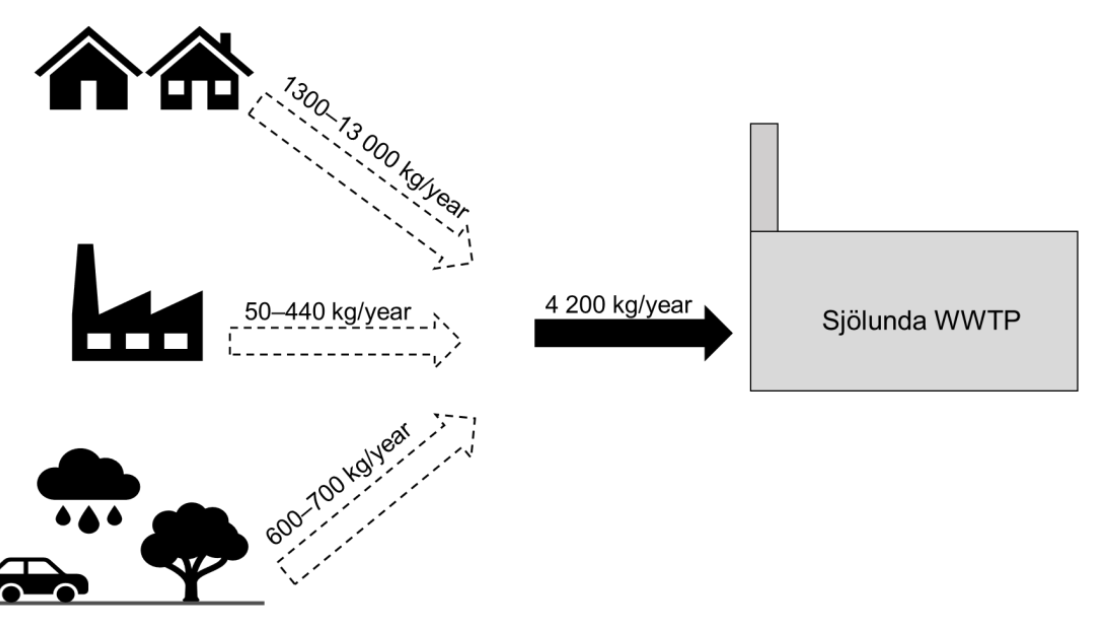

Figure 6: Overview of the contribution of microplastics from household-, enterprise- and stormwater sources to Sjölunda WWTP. The dashed arrows represent calculation-based estimates, and the filled arrow the measurement-based estimate. Reproduced from Paper II.

Some of the sources identified for Sjölunda WWTP are likely specific to the plant. This primarily concerns the contribution from enterprises, where the 
types of connected enterprises impact the microplastic contribution. Other sources to the WWTP are more general. The stormwater sources are likely similar for most WWTPs in cities, but the contribution is affected by contextspecific aspects, for example, the extent of combined sewers and amount of road in the catchment. Inflow and infiltration can vary greatly between WWTPs. At another large Swedish WWTP, it was determined that the majority of the microplastics originated from sources that were not households or householdrelated enterprises (Tumlin \& Bertholds, 2020), which was not the case for the calculation-based estimates for Sjölunda WWTP. However, at this WWTP, over $50 \%$ of the water to the WWTP is inflow and infiltration, while it is around $30 \%$ for Sjölunda WWTP. Still, the contribution from stormwater sources in the calculation-based estimates can be underestimated as several sources were not possible to quantify.

Household-related sources are probably similar to other regions with comparable standards, and the total load to the WWTP is mainly dependent on the number of households connected. The microplastic contribution originating from household-related sources has, in another study, been estimated to 3.1-10 $\mathrm{g} /$ capita/year (Tumlin \& Bertholds, 2020). For Sjölunda WWTP, this would mean that 1-3.4 tonnes/year originates from households, which is at the lower end of the calculation-based estimates for households to Sjölunda WWTP.

The large uncertainties concerning microplastic sources gave large intervals in the calculation-based estimates. Still, the results provide a preliminary overview of flows and highlight areas that need more attention. As a step to further the understanding of microplastic sources, we structured the calculation-based estimates according to microplastic types and compared them to the microplastic types in the samples collected in the influent at Sjölunda WWTP (Figure 7). The primary purpose of the comparison was to identify good matches and large differences. 


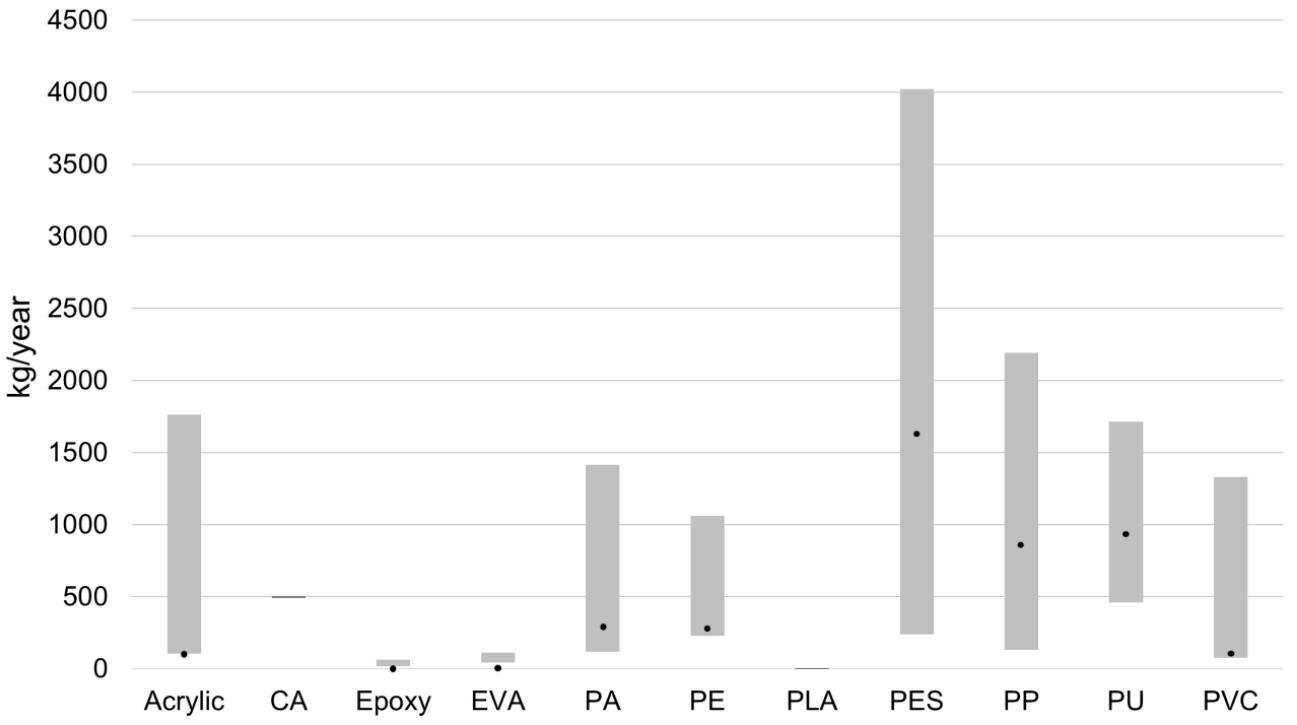

Figure 7: A comparison of calculation-based estimates and measurement-based estimates of microplastic types. The calculation-based estimated intervals of microplastic types to Sjölunda wastewater treatment plant shown in $\mathrm{kg} /$ year. The measurement-based estimates in $\mathrm{kg} /$ year at the inlet of Sjölunda wastewater treatment plant are shown as black dots. Based on data presented in Table 3 in Paper II. CA=cellulose acetate, EVA=ethylene vinyl acetate, $\mathrm{PA}=$ polyamide, $\mathrm{PE}=$ polyethylene, $\mathrm{PLA}=$ polylactic acid, PES=polyester, $\mathrm{PP}=$ polypropylene, $\mathrm{PU}=$ polyurethane and $\mathrm{PVC}=$ polyvinylchloride.

Polyester was the microplastic type with the largest contribution in the influent. The large majority of the polyester was estimated to come from laundry. This corroborates previous research, which has pointed to the significance of synthetic fibre release (e.g., Browne et al., 2011). Overall, laundry was estimated to be the largest source and stood for $40-89 \%$ of the total microplastic load to the WWTP. Although laundry is both an industrial and household activity, households were responsible for $96-97 \%$ of the calculation-based estimated load.

Cigarette filters consist of cellulose acetate, which, considering the conditions of Sjölunda WWTP, would stand for $4-26 \%$ of the total load. However, no cellulose acetate was found at the inlet. The reasons can be that cigarette filters are trapped in the primary screen at the WWTP or that they mostly do not break down into the sizes that are sampled as microplastics. Further, two microplastic types, alkyd, and polystyrene, were found at the inlet, but were not calculated. Alkyd and polystyrene can be associated with paint and littering, respectively, which were sources that were not possible to quantify in terms of microplastic 
types. The results indicate that there is a need to know more about paint and littering as sources of microplastics to urban waters.

As with the relative contribution of different sources, there are both contextual aspects and general conclusions that can be drawn regarding microplastic types in wastewater. PE and PP seem to be found at inlets of most WWTPs, but the dominating microplastic type can differ largely between WWTPs (Ngo et al., 2019). For Sjölunda WWTP, it was polyester, and this was also the case for a Finnish WWTP (Lares et al., 2018). At another Swedish WWTP, the largest contribution of microplastics at the inlet was PE (Tumlin \& Bertholds, 2020), which had a rather small share for Sjölunda WWTP (see Table 3, Paper II). However, for the household-related water to this WWTP, the contribution from polyester and PE was equally large. In a study of ten Danish WWTPs, acrylate dominated (Simon et al. 2018), and for a Scottish WWTP, it was alkyd (Murphy et al., 2016). Cellulose acetate does not seem to be detected at inlets of WWTPs in general (Ngo et al., 2019).

\subsection{Managing microplastics in urban waters}

New types of substances are continuously introduced to society or recognised as problems. This means that many kinds of pollution are being controlled or have been controlled by society. Past experiences of pollution control management and already existing strategies, such as upstream work, can be used to guide control for new types of substances, and the question of how it can give insights to the control of microplastics was posed in RQ2.

\subsubsection{Strategies and measures for microplastics in urban waters}

Despite the large uncertainties regarding flows of microplastics, several strategies and measures to handle the pollution have been proposed. The strategies and measures that were identified in Paper I are shown in Table 2. 
Table 2: Overview of the strategies and measures identified for microplastics, the type of strategy and the source for which the strategy or measure is aimed at controlling. This should not be seen as an exhaustive list, but as a list of examples. DF=disc filter, MBR=membrane bioreactor, DAF=dissolved air flotation and RSF=rapid sand filter. Reproduced from Paper I.

\begin{tabular}{|c|c|c|}
\hline Type & Source & Strategy/measure \\
\hline \multirow{11}{*}{ Preventive } & $\begin{array}{l}\text { Microbeads in personal } \\
\text { care products }\end{array}$ & Ban and substitution \\
\hline & \multirow[b]{2}{*}{ Laundry } & Change in practice: textile constructions \\
\hline & & $\begin{array}{l}\text { Change in washing and consumption } \\
\text { behaviour }\end{array}$ \\
\hline & Plastic pre-production & Enforcement of legislation \\
\hline & \multirow{2}{*}{ Artificial turfs } & Change in maintenance \\
\hline & & Substitution of filling material \\
\hline & Road traffic & Increase durability and resistance \\
\hline & \multirow{3}{*}{ Macroplastic } & Behavioural change \\
\hline & & Reduce plastic use \\
\hline & & Enhance waste management \\
\hline & Aggregated stormwater & Street sweepings \\
\hline \multirow{6}{*}{$\begin{array}{l}\text { Decentralised } \\
\text { treatment }\end{array}$} & \multirow{2}{*}{ Laundry } & Filter in washing machine \\
\hline & & Change in practice: pre-washings \\
\hline & Plastic pre-production & Drain filters \\
\hline & Artificial turfs & Granulate trap \\
\hline & Road traffic & Filter \\
\hline & Aggregated stormwater & Stormwater retention ponds \\
\hline $\begin{array}{l}\text { Centralised } \\
\text { treatment at } \\
\text { WWTP }\end{array}$ & Aggregated wastewater & $\begin{array}{l}\text { Additional treatment } \\
\text { technologies (e.g., DF, DAF, MBR, RSF) }\end{array}$ \\
\hline
\end{tabular}

Preventive strategies and measures prevent the occurrence of microplastics or prevent microplastics from entering the water. In 2018, a ban on microbeads that are rinsed off was implemented in Sweden. This means a reduction of approximately $473-526 \mathrm{~kg} /$ year of primarily PU and PE related to the flow estimates at Sjölunda WWTP. However, as the ban only concerns microplastics in products that are rinsed off, the source will not be eliminated. Personal care products that are not rinsed off were estimated to 358-742 kg/year for Sjölunda WWTP.

Decentralised treatment can be placed at source or in the open urban area, and centralised treatment is commonly located at WWTPs. Treatment removes microplastics that have been added to the water, and hence there is a residue to dispose of or utilise. Examples of decentralised treatment are filters adjacent to 
roads, in artificial turfs or in household washing machines. In Paper II, household laundry was identified as the largest source to the WWTP. Cesa et al. (2020) found that a filter retained $25-60 \%$ of the fibres when washing. If all households connected to Sjölunda WWTP had this filter, it could mean a reduction of $0.2-7$ tonnes/year. Treatment with membrane bioreactors and polishing steps, such as disc filters, dissolved air flotation, and rapid sand filters have also been shown to retain $40-99.9 \%$ of the microplastics (Lares et al., 2018; Simon et al., 2019; Talvitie et al., 2017).

\subsubsection{Considerations for the control of microplastics in urban waters}

Urban water management is primarily a municipal responsibility in Sweden, which means that urban water pollution control is primarily a municipal responsibility. However, different actors are involved depending on where in the urban water system the control takes place. WWTPs are owned by the municipalities, and control measures situated at the WWTP are the responsibility of the water and wastewater utilities. Regarding stormwater quality, the legal framework and responsibilities among actors that affect stormwater quality are less clear, and several municipal departments are involved. The Swedish Chemicals Agency is a key actor for preventive measures as this agency is responsible for chemical control and aids in legislation development. EU regulations, such as $\mathrm{REACH}$, also play an important role in minimising harmful substances in society in general. As indicated by the results in Paper II, households can be a significant source of microplastics. Compared to pollution from enterprises, there are not the same possibilities and structures in place to control pollution from households. The means at hand to control these flows are primarily information on a local level or product regulation on an EU or national level.

Unclear roles and responsibilities were identified as a challenge in relation to upstream work (Paper III). This may impact the control of microplastics as well. Both the water and wastewater utilities and environmental department are key actors for urban water pollution management on the local level. This collaboration is important both in relation to enterprises connected to the wastewater and concerning stormwater, where the responsibilities are even more unclear. This example illustrates that even if the responsibility is municipal, which can seem clear at first glance, it can still be an issue when several municipal departments are involved with their individual responsibilities, as well as time and financial constraints (Paper III). 
An aspect that might further complicate the issue of pollution control is that the actor that has the major responsibility and the actor that has the most authority or possibility to influence the pollution is not necessarily the same. Sörme et al. (2003), for example, showed that while wastewater utilities have responsibility for wastewater pollution, they often had limited capacity to influence the flows. This problem can be alleviated through collaboration with the municipal environmental department concerning upstream work. However, this collaboration was shown to function differently among municipalities (Paper III).

Several of the suggested measures for microplastics were preventive (Table 2). These primarily placed the responsibility on producers to change production to release less microplastics or citizens to change behaviour (see Table 4 in Paper I). Often, an authority also has responsibility for assuring compliance. Further, many measures will not eliminate the source but contribute to a reduced flow and preventive and treatment measures may have to be combined.

A distinct responsibility allocation has been argued to increase the likelihood of a solution being implemented (Sedlak, 2017). For the microplastic case, this may favour centralised treatment or efforts that place the responsibility on a producer or owner with an authority to assure compliance. However, specific for microplastics is also the problem that there is no accessible method for sampling and analysis, which makes it difficult to set limit values and control compliance. This issue can favour efforts that target microplastics that can be seen with the naked eye (for example granulate from artificial turfs) and preventive measures.

For control efforts based on treatment, pollution movement should be considered. Preventive measures typically do not cause pollution movement since the introduction of the substance to the system is avoided (Paper I). In connection with treatment, the pollution can be moved to sediments, sewage sludge, or solid waste. These compartments may be preferable in comparison to water. However, knowledge about where the pollution is located is still needed to ensure that the compartment is handled properly. For microplastics, several decentralised treatment alternatives suggest a move of microplastics to solid waste. This is an example of where pollution movement also leads to a responsibility shift from wastewater utilities to waste management. Plastic is already handled in solid waste management, and the increase due to, for example, an increase in plastic fibres from laundry would make a small difference in comparison to total waste volumes handled by the municipalities. 
Further, waste management already works against littering, with campaigns and by providing and emptying bins, and an increased use of these would not require a large change of practice.

For centralised treatment, pollution movement is primarily directed to the sewage sludge compartment. On the one hand, sewage sludge is a valuable resource, but on the other hand, a cocktail of undesirable substances. The three countries investigated in Paper I chose different strategies for sewage sludge management. These differences may affect which control alternatives are seen as appropriate. Both Sweden and Austria are members of the EU and must follow the sewage sludge directive (86/278/EEC). This directive encourages the reuse of sewage sludge. Switzerland is not part of the EU and is incinerating all sewage sludge (Chèvre et al., 2013). Incineration is also the most common use of sewage sludge in Austria, while in Sweden, only a small part (1\%) of the sludge is incinerated (Eurostat, 2020). In Sweden, upstream work has been an important strategy to increase sludge quality to enable its use as a fertiliser. However, if a new sludge regulation is introduced, Sweden may also move towards more incineration (Paper III), which can impact what measures are seen as appropriate in Sweden as well.

Pollution control through upstream work was sometimes shown to suffer from a lack of organisational or political motivation (Paper III). This does not seem to be the case for microplastics, where the motivation is large, despite the uncertainties and that the environmental effects are not fully understood. As shown in Figure 4, microplastics has received media attention, and this can be a reason for policy interventions despite the uncertainties. Taking actions can be a way of building a good reputation and showing leadership (Farrelly \& Brown, 2011) in relation to issues that are viewed as important by the public.

The case of microplastics raises questions about when and how pollution is going to be handled in society. Should pollution be handled when negative environmental consequences are proven, and in that case, when can it be considered proven? Or should the pollution be handled from a precautionary perspective, and since microplastics seems to be widespread in the environment and plastic does not belong in the environment, it should be handled? Should pollution control efforts be encouraged after first signs of adverse effects or can, specifically costly, control efforts only be motivated when there is a legal obligation? Pollution is continuously introduced to society and the issue of establishing long-term strategies was raised in Paper III. Instability, in terms of for example shifts in political power, may impede the establishment such 
strategies (Wilson et al., 2001). Some substances receive more attention than others, and what is seen as suitable control efforts are connected to values and goals that might be competing. Shifts in political power can therefore shift what is seen as valuable and important, both on a national and a local level. 


\section{Conclusion and outlook}

This chapter summarises the key findings of this thesis, presents possible future research directions, and discusses the issue of pollution control in a changing urban water system.

The aim of this thesis was to contribute to the understanding of flows of microplastics and investigate strategies and measures to handle these flows, based on strategies and measures that exist today. Related to flows, it can be concluded that laundry seems to be a large source of microplastics to WWTPs, but that cigarette filters constitute a smaller source than anticipated. Further, there is a limited understanding of most of the sources of microplastics. Some sources have been researched more than others but still give ambiguous results, while there is very limited knowledge for other sources. For wastewater, this particularly concerns paint and personal care products that are not rinsed off, and for stormwater, it regards paint and litter. For litter, there is specifically a need to know more about transport pathways and break down processes. For paint, in addition to the above-mentioned aspects, an understanding of how much of the polymer content that can be considered microplastics would also need increased attention.

Despite the limited understanding of microplastic flows, several strategies and measures have been suggested for microplastics, both preventive and in terms of treatment. Some aspects that influence the implementation of control efforts are related to the properties and behaviour of the specific pollutant and can therefore be more or less suitable for different pollutants. Other aspects are more general, such as what compartments are prioritised in terms of protection. Challenges related to changing, limited or even lack of legislation, unclear responsibilities, as well as problems with collaboration among urban actors also impact the possibilities to control pollution.

\subsection{Future research}

In this thesis, microplastic pollution has been placed in the context of the current urban water pollution regime. More research is needed in this area, both related to the development of more detailed overviews of flows of microplastics and connecting these flows to actors and responsibility. Paper II gave some new perspectives on flows to a WWTP, and this can be further developed by adding more WWTPs with different characteristics in terms of size, sources and amount of inflow and infiltration. Further, to increase the understanding of flows of microplastics, future research can be expanded to include the larger urban 
water system. Paper III revealed some aspects specifically regarding responsibility and collaboration between urban actors that need to be considered, and Paper I showed that several actors are commonly involved in the suggested control strategies and measures for microplastics. In future research, the responsibility of urban actors (beyond water and wastewater utilities) could be connected to the flows of microplastics, as well to potential control efforts, to deepen the understanding of who has responsibility for and the possibility to control the flows of microplastics in urban waters.

\subsection{Outlook}

The urban water system is changing, both in relation to stormwater and wastewater. Combined sewers are no longer constructed in Sweden and some of the combined sewers are being separated, which means that less stormwater will be treated at the WWTP. This is desirable from several perspectives. Separating the pipe system reduces combined sewer overflows. Further, too much cold, nutrient-poor stormwater reduces the function of the treatment at the WWTP. In addition, pollution present in stormwater is not added to the WWTP when the pipe system is separated, which will positively impact sludge quality. However, the obvious drawback is the loss of control over emissions. The majority of the stormwater in Sweden is not treated, and the pollution will enter and deteriorate receiving waterways, making it difficult to reach a good ecological status, as stated in the Water Framework Directive. This may also increase the need for advances in the upstream work for stormwater.

The perception of wastewater is changing from waste to resource, through the re-use of treated wastewater and utilisation of the sludge, for nutrients, biofuel, or metals (Villarín \& Merel, 2020). One emerging wastewater solution is source separation (Larsen et al., 2016). Separating toilet water (blackwater) from other household water (greywater, e.g., water from washing machines, showers, and sinks) already at the household level allows for new opportunities for treatment and resource utilisation. Most microplastics from the households will enter the wastewater via greywater, which means that this flow could be treated. Most of the nutrients would instead be found in blackwater, giving the potential for sewage sludge use as fertiliser, with very limited microplastic content. These emerging practices challenge the traditional views on treatment and the linear view of the wastewater system, which in turn will impact how we view upstream and downstream in the urban water system. 


\section{References}

Amec Foster Wheeler. (2017). Intentionally added microplastics in products. London, Great Britain: Author.

Amneklev, J. (2015). Diffuse emissions from goods: influences on some societal end products. Doctoral dissertation. Växjö, Sweden: Linnaeus University Press.

Amneklev, J., Augustsson, A., Sörme, L., \& Bergbäck, B. (2016). Bismuth and Silver in Cosmetic Products: A Source of Environmental and Resource Concern?: Bismuth and Silver in Cosmetic Products. Journal of Industrial Ecology, 20(1), 99-106. https://doi.org/10.1111/jiec.12251

Anderberg, S., \& Stigliani, W. M. (1994). An Integrated Approach for Identifying Sources of Pollution: The Example of Cadmium Pollution in the Rhine River Basin. Water Science and Technology, 29(3), 61-67. https://doi.org/10.2166/wst.1994.0064

Arthur, C., Baker, J. \& Bamford, H. Proceedings of the international research workshop on the occurrence, effects and fate of microplastic marine debris, Sept 9 -11, 2008; National Oceanic and Atmospheric Administration: 2009.

Azapagic, A., Pettit, C., \& Sinclair, P. (2007). A life cycle methodology for mapping the flows of pollutants in the urban environment. Clean Technologies and Environmental Policy, 9(3), 199-214. https://doi.org/10.1007/s10098-007-0092-9

Barles, S. (2010). Society, energy and materials: The contribution of urban metabolism studies to sustainable urban development issues. Journal of Environmental Planning and Management, 53:4, 439-455, https://doi.org/10.1080/09640561003703772

Beloin-Saint-Pierre, D., Rugani, B., Lasvaux, S., Mailhac, A., Popovici, E., Sibiude, G., Benetto, E., \& Schiopu, N. (2017). A review of urban metabolism studies to identify key methodological choices for future harmonization and implementation. Journal of Cleaner Production, 163, S223-S240. https://doi.org/10.1016/j.jclepro.2016.09.014

Bengtsson, M., \& Tillman, A.-M. (2004). Actors and interpretations in an environmental controversy: The Swedish debate on sewage sludge use in agriculture. Resources, Conservation and Recycling, 42(1), 65-82. https://doi.org/10.1016/j.resconrec.2004.02.004

Bergbäck, B., Johansson, K., \& Mohlander, U. (2001). Urban metal flows-a case study of Stockholm. Review and Conclusions. Water, air and soil pollution: Focus, 1(3-4), 3-24. 
Blettler, M. C. M., Abrial, E., Khan, F. R., Sivri, N., \& Espinola, L. A. (2018).

Freshwater plastic pollution: Recognizing research biases and identifying knowledge gaps. Water Research, 143, 416-424. https://doi.org/10.1016/j.watres.2018.06.015

Bläsing, M., \& Amelung, W. (2018). Plastics in soil: Analytical methods and possible sources. Science of The Total Environment, 612, 422-435. https://doi.org/10.1016/j.scitotenv.2017.08.086

Bollman, U.E., Vollertsen, J., Carmeliet, J. \& Bester, K. (2014). Dynamics of biocide emissions from buildings in a suburban stormwater catchment e Concentrations, mass loads and emission processes. Water Research, 56, 66-76. https://doi.org/10.1016/j.watres.2014.02.0330043-1354/

Bowen, G. (2009). Document analysis as a qualitative research method. Qualitative Research Journal, 9, (2), 27-40. https://doi.org/10.3316/QRJ0902027.

Browne, M. A., Crump, P., Niven, S. J., Teuten, E., Tonkin, A., Galloway, T., \& Thompson, R. (2011). Accumulation of Microplastic on Shorelines Woldwide: Sources and Sinks. Environmental Science \& Technology, 45(21), 9175-9179. https://doi.org/10.1021/es201811s

Brown, R.R. (2005). Impediments to Integrated Urban Stormwater Management: The Need for Institutional Reform. Environmental Management, 36(3), 455-468. https://doi.org/10.1007/s00267-004-0217-4

Brown, R. R., \& Farrelly, M. A. (2009). Delivering sustainable urban water management: A review of the hurdles we face. Water Science and Technology, 59(5), 839-846. https://doi.org/10.2166/wst.2009.028

Brunner, P.H. (2012). Substance flow analysis: a key tool for effective resource management. Journal of Industrial Ecology 16(3), 293-295. https://doi.org/ 10.1111/j.1530-9290.2012.00496.x

Brunner, P. H., \& Rechberger, H. (2004). Practical handbook of material flow analysis. Lewis Publishers.

Bryman, A. (2016). Social research methods. Oxford university press.

Cesa, F. S., Turra, A., Checon, H. H., Leonardi, B., \& Baruque-Ramos, J. (2020). Laundering and textile parameters influence fibers release in household washings. Environmental Pollution, 257, 113553.

https://doi.org/10.1016/j.envpol.2019.113553

Chèvre, N., Guignard, C., Rossi, L., Pfeifer, H.-R., Bader, H.-P., \& Scheidegger, R. (2011). Substance flow analysis as a tool for urban water management. Water Science and Technology, 63(7), 1341-1348. https://doi.org/10.2166/wst.2011.132 
Chèvre, N., Coutu, S., Margot, J., Wynn, H. K., Bader, H.-P., Scheidegger, R., \& Rossi, L. (2013). Substance flow analysis as a tool for mitigating the impact of pharmaceuticals on the aquatic system. Water Research, 47(9), 2995-3005. https://doi.org/10.1016/j.watres.2013.03.004

Churchman, C. W. (1968). The systems approach. Delta.

Cole, M., Lindeque, P., Halsband, C., \& Galloway, T. S. (2011). Microplastics as contaminants in the marine environment: A review. Marine Pollution Bulletin, 62(12), 2588-2597.

https://doi.org/10.1016/j.marpolbul.2011.09.025

Creswell, J. W. (2014). Research Design: qualitative, quantitative and mixed methods approaches. Thousand Oaks.

Dagerskog, L., \& Olsson, O. (2020). Swedish sludge management at the crossroads. Stockholm Environment Institute.

Davis, M.L. (2010). Water and Wastewater Engineering. Design Principles and Practice. McGraw Hill.

Decker, E. H., Elliott, S., Smith, F. A., Blake, D. R., \& Rowland, F. S. (2000). Energy and material flow through the urban ecosystem. Annual Review of Energy and the Environment, 25(1), 685-740. https://doi.org/10.1146/annurev.energy.25.1.685

De Falco, F., Gullo, M. P., Gentile, G., Di Pace, E., Cocca, M., Gelabert, L., Brouta-Agnésa, M., Rovira, A., Escudero, R., Villalba, R., Mossotti, R., Montarsolo, A., Gavignano, S., Tonin, C., \& Avella, M. (2018).

Evaluation of microplastic release caused by textile washing processes of synthetic fabrics. Environmental Pollution, 236, 916-925.

https://doi.org/10.1016/j.envpol.2017.10.057

de Sá, L. C., Oliveira, M., Ribeiro, F., Rocha, T. L., \& Futter, M. N. (2018).

Studies of the effects of microplastics on aquatic organisms: What do we know and where should we focus our efforts in the future? Science of The Total Environment, 645, 1029-1039.

https://doi.org/10.1016/j.scitotenv.2018.07.207

Dris, R., Gasperi, J., Mirande, C., Mandin, C., Guerrouache, M., Langlois, V., \& Tassin, B. (2017). A first overview of textile fibers, including microplastics, in indoor and outdoor environments. Environmental Pollution, 221, 453-458. https://doi.org/10.1016/j.envpol.2016.12.013

Eerkes-Medrano, D., Thompson, R. C., \& Aldridge, D. C. (2015). Microplastics in freshwater systems: A review of the emerging threats, identification of knowledge gaps and prioritisation of research needs. Water Research, 75, 63-82. https://doi.org/10.1016/j.watres.2015.02.012 
Eriksson, E., Revitt, D. M., Ledin, A., Lundy, L., Holten Lützhøft, H. C., Wickman, T., \& Mikkelsen, P. S. (2011). Water management in cities of the future using emission control strategies for priority hazardous substances. Water Science and Technology, 64(10), 2109-2118. https://doi.org/10.2166/wst.2011.797

Estahbanati, S. \& Fahrenfeld, N. L. (2016). Influence of wastewater treatment plant discharges on microplastic concentrations in surface water.

Chemosphere, 162, 277-284.

https://doi.org/10.1016/j.chemosphere.2016.07.083

European Commission (2001). Disposal and recycling routes for sewage sludge. Part 1- Sludge use acceptance. Luxembourg: Office for Official Publications of the European Communities.

Eurostat (2020). Sewage sludge production and disposal.

https://ec.europa.eu/eurostat/web/products-

datasets/product?code=env_ww_spd Accessed: $19^{\text {th }}$ October 2020

Farrelly, M., \& Brown, R. (2011). Rethinking urban water management:

Experimentation as a way forward? Global Environmental Change, 21(2), 721-732. https://doi.org/10.1016/j.gloenvcha.2011.01.007

Fältström, E., Gustafsson, S., Hagman, M., Wittgren, HB. \& Anderberg, S.

(2018). Kommunperspektiv på uppströmsarbete i Sverige idag och i framtiden. Rapport 2018-09. Stockholm, Sweden: Svenskt Vatten Utveckling.

GESAMP (2015). Sources, fate and effects of microplastics in the marine environment: a global assessment. (Kershaw, P. J., ed.). (IMO/FAO/ UNESCO-IOC/UNIDO/WMO/IAEA/UN/UNEP/UNDP Joint Group of Experts on the Scientific Aspects of Marine Environmental Protection). Rep. Stud. GESAMP No. 90, 96 p

Habib, R. Z., Thiemann, T., \& Al Kendi, R. (2020). Microplastics and Wastewater Treatment Plants - A Review. Journal of Water Resource and Protection, 12(01), 1-35. https://doi.org/10.4236/jwarp.2020.121001

Hartmann, N. B., Hüffer, T., Thompson, R. C., Hassellöv, M., Verschoor, A., Daugaard, A. E., Rist, S., Karlsson, T., Brennholt, N., Cole, M., Herrling, M. P., Hess, M. C., Ivleva, N. P., Lusher, A. L., \& Wagner, M. (2019). Are We Speaking the Same Language? Recommendations for a Definition and Categorization Framework for Plastic Debris. Environmental Science $\mathcal{E}$ Technology, 53(3), 1039-1047. https://doi.org/10.1021/acs.est.8b05297 Hidalgo-Ruz, V., Gutow, L., Thompson, R. C., \& Thiel, M. (2012). Microplastics in the Marine Environment: A Review of the Methods Used for 
Identification and Quantification. Environmental Science \& Technology, 46(6), 3060-3075. https://doi.org/10.1021/es2031505

Hjelmqvist, J., Sjögren, E., Blecken, G.T., Österlund, H., Rydberg, A. \& Hassel, A. (2017). Att definiera normaldagvatten: förslag och resonemang. Rapport 2017-12. Stockholm, Sweden: Svenskt Vatten Utveckling. Hudcová, H., Vymazal, J., Rozkošný M. (2019): Present restrictions of sewage sludge application in agriculture within the European Union. Soil and Water Research, 14: 104-120. https://doi.org/10.17221/36/2018-SWR Hu, Y., Gong, M., Wang, J., \& Bassi, A. (2019). Current research trends on microplastic pollution from wastewater systems: A critical review. Reviews in Environmental Science and Bio/Technology, 18(2), 207-230. https://doi.org/10.1007/s11157-019-09498-w

Hvitved-Jacobsen, T., Vollertsen, J., \& Nielsen, A. H. (2010). Urban and highway stormwater pollution: concepts and engineering. CRC press.

Irvine, A., Drew, P. and Sainsbury, R. (2013) 'Am I not answering your questions properly?' Clarification, adequacy and responsiveness in semi-structured telephone and face-to-face interviews, Qualitative Research, 13, 1, 87-106.

Jambeck, J. R., Geyer, R., Wilcox, C., Siegler, T. R., Perryman, M., Andrady, A., ... \& Law, K. L. (2015). Plastic waste inputs from land into the ocean. Science, 347(6223), 768-771.

Jensen, J. \& Jepsen, S. E. (2005). The production, use and quality of sewage sludge in Denmark. Waste Management, 25(3), 239-247. https://doi.org/10.1016/j.wasman.2004.08.011

Karlsson, T. M., Arneborg, L., Broström, G., Almroth, B. C., Gipperth, L., \& Hassellöv, M. (2018). The unaccountability case of plastic pellet pollution. Marine Pollution Bulletin, 129(1), 52-60.

https://doi.org/10.1016/j.marpolbul.2018.01.041

Kennedy, C., Cuddihy, J., Engel-Yan, J. (2007). The changing metabolism of cities. Journal of Industrial Ecology, 11, 43-59. https://doi.org/10.1162/jie.2007.1107.

Kennedy, C., Pincetl, S., \& Bunje, P. (2011). The study of urban metabolism and its applications to urban planning and design. Environmental Pollution, 159(8-9), 1965-1973.

https://doi.org/10.1016/j.envpol.2010.10.022

Kiparsky, M., Sedlak, D. L., Thompson Jr, B. H., \& Truffer, B. (2013). The innovation deficit in urban water: the need for an integrated perspective on institutions, organizations, and technology. Environmental Engineering Science, 30(8), 395-408. https://doi.org/10.1089/ees.2012.0427 
Koelmans, A. A., Mohamed Nor, N. H., Hermsen, E., Kooi, M., Mintenig, S. M., \& De France, J. (2019). Microplastics in freshwaters and drinking water: Critical review and assessment of data quality. Water Research, 155, 410-422. https://doi.org/10.1016/j.watres.2019.02.054

Kole, P. J., Löhr, A. J., Van Belleghem, F., \& Ragas, A. (2017). Wear and Tear of Tyres: A Stealthy Source of Microplastics in the Environment.

International Journal of Environmental Research and Public Health, 14(10), 1265. https://doi.org/10.3390/ijerph14101265

Laner, D., Rechberger, H., \& Astrup, T. (2014). Systematic Evaluation of

Uncertainty in Material Flow Analysis: Uncertainty Analysis in Material Flow Analysis. Journal of Industrial Ecology, 18(6), 859-870.

https://doi.org/10.1111/jiec.12143

Laner, D., Rechberger, H., \& Astrup, T. (2015). Applying Fuzzy and

Probabilistic Uncertainty Concepts to the Material Flow Analysis of Palladium in Austria: Uncertainty Analysis of Austrian Palladium Budget. Journal of Industrial Ecology, 19(6), 1055-1069.

https://doi.org/10.1111/jiec.12235

Lares, M., Ncibi, M. C., Sillanpää, M., \& Sillanpää, M. (2018). Occurrence, identification and removal of microplastic particles and fibers in conventional activated sludge process and advanced MBR technology. Water Research, 133, 236-246. https://doi.org/10.1016/j.watres.2018.01.049

Larsen, T. A., Hoffmann, S., Luthi, C., Truffer, B., \& Maurer, M. (2016). Emerging solutions to the water challenges of an urbanizing world. Science, 352(6288), 928-933. https://doi.org/10.1126/science.aad8641

Lederer, J., \& Kral, U. (2015). Theodor Weyl: A Pioneer of Urban Metabolism Studies: Theodor Weyl, Pioneer of Urban Metabolism Studies. Journal of Industrial Ecology, 19(5), 695-702. https://doi.org/10.1111/jiec.12320

Libralato, G., Volpi Ghirardini, A., \& Avezzù, F. (2012). To centralise or to decentralise: An overview of the most recent trends in wastewater treatment management. Journal of Environmental Management, 94(1), 6168. https://doi.org/10.1016/j.jenvman.2011.07.010

Li, J., Liu, H., \& Paul Chen, J. (2018). Microplastics in freshwater systems: A review on occurrence, environmental effects, and methods for microplastics detection. Water Research, 137, 362-374. https://doi.org/10.1016/j.watres.2017.12.056

Liu, F., Olesen, K. B., Borregaard, A. R., \& Vollertsen, J. (2019). Microplastics in urban and highway stormwater retention ponds. Science of The Total Environment, 671, 992-1000. https://doi.org/10.1016/j.scitotenv.2019.03.416 
Ljung, E. Olesen, K.B., Andersson, P-G. Fältström, E., Vollertsen, J., Wittgren, HB \& Hagman, M. (2018). Mikroplaster i kretsloppet. 2018-13.

Stockholm, Sweden: Svenskt Vatten Utveckling.

Luo, Y., Guo, W., Ngo, H. H., Nghiem, L. D., Hai, F. I., Zhang, J., ... \& Wang, X.

C. (2014). A review on the occurrence of micropollutants in the aquatic environment and their fate and removal during wastewater treatment. Science of the Total Environment, 473, 619-641.

Lusher, A. L., Tirelli, V., O'Connor, I., \& Officer, R. (2015). Microplastics in Arctic polar waters: The first reported values of particles in surface and sub-surface samples. Scientific Reports, 5(1), 14947.

https://doi.org/10.1038/srep14947

Magnusson, K., Eliasson, K., Fråne, A., Haikonen, K., Hultén, J., Olshammar, M.,...Voisin, A. (2016). Swedish sources and pathways for microplastics to the marine environment $-A$ review of existing data. (C 138). Revised in March 2017. Stockholm, Sweden: IVL Swedish Environmental Research Institute

Malmqvist, P.-A., Kärrman, E., \& Rydhagen, B. (2006). Evaluation of the ReVAQ project to achieve safe use of wastewater sludge in agriculture. Water Science and Technology, 54(11-12), 129-135.

https://doi.org/10.2166/wst.2006.759

McDevitt, J. P., Criddle, C. S., Morse, M., Hale, R. C., Bott, C. B., \& Rochman, C. M. (2017). Addressing the Issue of Microplastics in the Wake of the Microbead-Free Waters Act-A New Standard Can Facilitate Improved Policy. Environmental Science \& Technology, 51(12), 6611-6617. https://doi.org/10.1021/acs.est.6b05812

Meadows, D. H. (2008). Thinking in systems: A primer. Chelsea green publishing.

Murphy, F., Ewins, C., Carbonnier, F., \& Quinn, B. (2016). Wastewater

Treatment Works (WwTW) as a Source of Microplastics in the Aquatic Environment. Environmental Science \& Technology, 50(11), 5800-5808. https://doi.org/10.1021/acs.est.5b05416

Napper, I. E., Bakir, A., Rowland, S. J., \& Thompson, R. C. (2015).

Characterisation, quantity and sorptive properties of microplastics extracted from cosmetics. Marine Pollution Bulletin, 99(1-2), 178-185. https://doi.org/10.1016/j.marpolbul.2015.07.029

Nathanson, J.A. (2020). Pollution. In Encyclopaedia Britannica Online. https://www.britannica.com/science/pollution-environment Accessed: $19^{\text {th }}$ October 2020 
National Library of Sweden. (n.d.) Svenska dagstidningar. [database]. https://tidningar.kb.se/

Nawaz, T., \& Sengupta, S. (2019). Contaminants of Emerging Concern:

Occurrence, Fate, and Remediation. In Advances in Water Purification Techniques (pp. 67-114). Elsevier.

Ngo, P. L., Pramanik, B. K., Shah, K., \& Roychand, R. (2019). Pathway, classification and removal efficiency of microplastics in wastewater treatment plants. Environmental Pollution, 255, 113326.

https://doi.org/10.1016/j.envpol.2019.113326

Nizzetto, L., Futter, M., \& Langaas, S. (2016). Are agricultural soils dumps for microplastics of urban origin?.Environmental Science \& Technology, 50, 10777-10779. https://doi.org/10.1021/acs.est.6b04140

Olesen, K.B., Stephansen, Alst, \& Vollertsen, J. (2019). Microplastics in a Stormwater Pond. Water, 11(7), 1466. https://doi.org/10.3390/w11071466 Olsson, M.O. \& Sjöstedt, G. (2005). Systems Approaches and Their Application. Examples from Sweden. Kluwer academic publishers.

Oluniyi Solomon, O., \& Palanisami, T. (2016). Microplastics in the Marine Environment: Current Status, Assessment Methodologies, Impacts and Solutions. Journal of Pollution Effects \& Control, 04(02).

https://doi.org/10.4172/2375-4397.1000161

Opdenakker, R. (2006). Advantages and disadvantages of four interview techniques in qualitative research. Forum: Qualitative Social Research, 7 (4) Article 11.

Pettipas, S., Bernier, M., \& Walker, T. R. (2016). A Canadian policy framework to mitigate plastic marine pollution. Marine Policy, 68, 117-122. https://doi.org/10.1016/j.marpol.2016.02.025

Pollans, L. B. (2017). Trapped in trash: 'Modes of governing' and barriers to transitioning to sustainable waste management. Environment and Planning A, 49(10), 2300-2323. https://doi.org/10.1177/0308518X17719461 Revaq (2019). Årsrapport 2018. Stockholm, Sweden: Svenskt Vatten. Revaq (2020). Regler för certifieringssystemet. Stockholm, Sweden: Svenskt Vatten.

Revitt, D. M., Lundy, L., Eriksson, E., \& Viavattene, C. (2013). Comparison of pollutant emission control strategies for cadmium and mercury in urban water systems using substance flow analysis. Journal of Environmental Management, 116, 172-180. https://doi.org/10.1016/j.jenvman.2012.12.007 Rochman, C. M., Tahir, A., Williams, S. L., Baxa, D. V., Lam, R., Miller, J. T., ... \& Teh, S. J. (2015). Anthropogenic debris in seafood: Plastic debris and 
fibers from textiles in fish and bivalves sold for human consumption. Scientific reports, 5, 14340.

Sedlak, D. (2017). Three lessons for the microplastics voyage. Environmental Science \& Technology, 51, 7747-7748. https://doi.org/10.1021/acs.est.7b03340

Shim, W. J., Hong, S. H., \& Eo, S. E. (2017). Identification methods in microplastic analysis: A review. Analytical Methods, 9(9), 1384-1391. https://doi.org/10.1039/C6AY02558G

Simon, M., van Alst, N., \& Vollertsen, J. (2018). Quantification of microplastic mass and removal rates at wastewater treatment plants applying Focal Plane Array (FPA)-based Fourier Transform Infrared (FT-IR) imaging. Water Research, 142, 1-9. https://doi.org/10.1016/j.watres.2018.05.019

Simon, M., Vianello, A., \& Vollertsen, J. (2019). Removal of $>10 \mu \mathrm{m}$ Microplastic Particles from Treated Wastewater by a Disc Filter. Water, 11(9), 1935. https://doi.org/10.3390/w11091935

Statens offentliga utredningar (2020). Hållbar slamhantering. Betänkande av Utredningen om en giftfri och cirkulär återföring av fosfor från avloppsslam. SOU 2020:3. Stockholm: Author.

Statistics Sweden (n.d.) Län och kommuner. Counties and municipalities. https://www.scb.se/hitta-statistik/regional-statistik-och-kartor/regionalaindelningar/lan-och-kommuner/ Accessed: $19^{\text {th }}$ October 2020

Statistics Sweden (2020). Utsläppen av fosfor har ökat. https://www.scb.se/hitta-statistik/statistik-efteramne/miljo/utslapp/utslapp-till-vatten-och-slamproduktion-kommunala-reningsverk-skogsindustri-samt-viss-ovrigindustri/pong/statistiknyhet/utslapp-till-vatten-och-slamproduktion2018/ Accessed: $19^{\text {th }}$ October 2020

Sun, J., Dai, X., Wang, Q., van Loosdrecht, M. C. M., \& Ni, B.-J. (2019).

Microplastics in wastewater treatment plants: Detection, occurrence and removal. Water Research, 152, 21-37.

https://doi.org/10.1016/j.watres.2018.12.050

Swedish Chemicals Agency (2020). Svenska regler om plastpartiklar i kosmetiska produkter. https://www.kemi.se/lagar-och-regler/reglersom-endast-galler-i-sverige/nationella-begransningar-ochforbud/svenska-regler-om-plastpartiklar-i-kosmetiska-produkter Accessed: 15th October 2020

Swedish EPA (2013). Hållbar återföring av fosfor. Naturvårdsverkets redovisning av ett uppdrag från regeringen. Rapport 6580. Stockholm, Sweden: Author. 
Swedish EPA (2016). Rening av avloppsvatten i Sverige 2016. Stockholm, Sweden: Author.

Swedish EPA (2017). Analys av kunskapsläget för dagvattenproblematiken.

Redovisning av redovisningsuppdrag. NV-08972-16 Stockholm, Sweden: Author.

Swedish Water and Wastewater Association (2016). Avledning av dag- dränoch spillvatten. Funktionskrav, hydraulisk dimensionering och utformning av allmänna avloppssystem. Publikation P110 - Del 1. Stockholm, Sweden: Author.

Swedish Water and Wastewater Association (2017). Jakt pågår. Reningsverk, handeln och konsumenter i samma lag när farliga ämnen spåras. Meddelande M 144. Stockholm, Sweden: Author.

Swedish Water and Wastewater Association (2019). Råd vid mottagande av avloppsvatten från industri och annan verksamhet. Publikation P95. Stockholm, Sweden: Author.

Sörme, L., \& Lagerkvist, R. (2002). Sources of heavy metals in urban wastewater in Stockholm. Science of the Total Environment, 298(1-3), 131145.

Sörme, L., Lindqvist, A. \& Söderberg, H. (2003). Capacity to influence sources of heavy metals to wastewater treatment sludge. Environmental Management, 31(3), 0421-0428

Talvitie, J., Mikola, A., Koistinen, A., \& Setälä, O. (2017). Solutions to microplastic pollution-Removal of microplastics from wastewater effluent with advanced wastewater treatment technologies. Water Research, 123, 401-407. http://dx.doi.org/10.1016/j.watres.2017.07.005 Thomasson, A. (2013). Organisering för ökad uthållighet. En studie av olika organisationsformer inom den svenska VA-sektorn. Rapport Nr 201313. Stockhom, Sweden: Svenskt Vatten Utveckling.

Thomasson, A. (2015). Att driva VA i egen förvaltning-den lilla kommunens erfarenheter och utmaningar. Rapport Nr 2015-23. Stockholm, Sweden: Svenskt Vatten Utveckling.

Thompson, M. A., Owen, S., Lindsay, J. M., Leonard, G. S., \& Cronin, S. J. (2017). Scientist and stakeholder perspectives of transdisciplinary research: Early attitudes, expectations, and tensions. Environmental Science \& Policy, 74, 30-39. https://doi.org/10.1016/j.envsci.2017.04.006 Thompson, R. C., Olsen, Y., Mitchell, R. P., Davis, A., Rowland, S. J., John, A. W., ... \& Russell, A. E. (2004). Lost at sea: where is all the plastic? Science 304(5672), 838. https://doi.org/10.1126/science.1094559 
Tibbetts, J., Krause, S., Lynch, I., \& Sambrook Smith, G. (2018). Abundance, Distribution, and Drivers of Microplastic Contamination in Urban River Environments. Water, 10(11), 1597. https://doi.org/10.3390/w10111597

Tumlin, S. (2017). Microplastics - Report from an IWA SWeden conference and workshop in Malmö, November 8-9, 2017. VA-teknik Södra.

Tumlin, S. Bertholds, C. (2020). Kartläggning av mikroplaster - till, inom och från avloppsreningsverk. Rapport Nr. 2020-8. Stockholm, Sweden: Author.

United Nations (2015). Resolution adopted by the General Assembly on 25

September 2015, Transforming our world: the 2030 Agenda for Sustainable Development.

Unice, K. M., Kreider, M. L., \& Panko, J. M. (2013). Comparison of Tire and Road Wear Particle Concentrations in Sediment for Watersheds in France, Japan, and the United States by Quantitative Pyrolysis GC/MS Analysis. Environmental Science \& Technology, 130710100101002. https://doi.org/10.1021/es400871j

Vandermeersch, G., Van Cauwenberghe, L., Janssen, C. R., Marques, A., Granby, K., Fait, G., Kotterman, M. J. J., Diogène, J., Bekaert, K., Robbens, J., \& Devriese, L. (2015). A critical view on microplastic quantification in aquatic organisms. Environmental Research, 143, 46-55. https://doi.org/10.1016/j.envres.2015.07.016 van der Voet, E. (2002). Substance flow analysis methodology. In Ayres, R. U., \& Ayres, L. (Eds.). A Handbook of Industrial Ecology (91-101). Edward Elgar Publishing.

van der Voet, E., van Egmond, L., Kleijn, R., \& Huppes, G. (1994). Cadmium in the European community: a policy-oriented analysis. Waste Management $\mathcal{E}$ Research, 12(6), 507-526.

VA SYD (2018). Sjölunda Avloppsreningsverk Malmö. Miljörapport 2017.

Malmö, Sweden: Author.

VA SYD (2020a) Bräddning i Malmö

https://www.vasyd.se/Artiklar/Avlopp/Braddning-i-Malmo Accessed: $19^{\text {th }}$ October 2020

VA SYD (2020b) Sjölunda avloppsreningsverk

https://www.vasyd.se/Artiklar/Avlopp/Avloppsreningsverk/Sjolundaavloppsreningsverk Accessed: 19 $9^{\text {th }}$ October 2020

Verschoor, A., de Poorter, L., Dröge, R., Kuenen, J. \& de Valk, E. (2016).

Emission of microplastics and potential mitigation measures Abrasive cleaning agents, paints and tyre wear. RIVM Report 2016-0026. 
Bilthoven, Netherlands: National Institute for Public Health and the Environment.

Vianello, A., Jensen, R. L., Liu, L., \& Vollertsen, J. (2019). Simulating human exposure to indoor airborne microplastics using a Breathing Thermal Manikin. Scientific Reports, 9(1), 8670. https://doi.org/10.1038/s41598-01945054-w

Villarín, M. C., \& Merel, S. (2020). Paradigm shifts and current challenges in wastewater management. Journal of Hazardous Materials, 390, 122139. https://doi.org/10.1016/j.jhazmat.2020.122139

Wihlborg, M., Sörensen, J., \& Alkan Olsson, J. (2019). Assessment of barriers and drivers for implementation of blue-green solutions in Swedish municipalities. Journal of Environmental Management, 233, 706-718. https://doi.org/10.1016/j.jenvman.2018.12.018

Wilson, E. J., McDougall, F. R., \& Willmore, J. (2001). Euro-trash: Searching Europe for a more sustainable approach to waste management. Resources, Conservation and Recycling, 31(4), 327-346. https://doi.org/10.1016/S0921-3449(00)00089-6

Wolman, A. (1965). The metabolism of cities. Scientific American, 213(3), 178193.

Wright, S. L., Ulke, J., Font, A., Chan, K. L. A., \& Kelly, F. J. (2020). Atmospheric microplastic deposition in an urban environment and an evaluation of transport. Environment International, 136, 105411. https://doi.org/10.1016/j.envint.2019.105411

Xanthos, D., \& Walker, T. R. (2017). International policies to reduce plastic marine pollution from single-use plastics (plastic bags and microbeads): A review. Marine Pollution Bulletin, 118(1-2), 17-26. https://doi.org/10.1016/j.marpolbul.2017.02.048 
Appendix 



\section{Papers}

The papers associated with this thesis have been removed for copyright reasons. For more details about these see:

http://urn.kb.se/resolve?urn=urn:nbn:se:liu:diva-171095 


\section{FACULTY OF SCIENCE AND ENGINEERING}

Linköping Studies in Science and Technology, Licentiate Thesis No. 1888, 2020 Department of Management and Engineering

Linköping University

SE-581 83 Linköping, Sweden

WWW.liu.se 